\title{
Border Matters: Redefining the National Interest in U.S.-Mexico Immigration and Trade Policy
}

\author{
Gabriela A. Gallegos ${ }^{\dagger}$
}

\section{TABLE OF CONTENTS}

Introduction

I. The Standard Story: Economics-Based Justifications for Trade and Immigration Policies

A. Macroeconomics-Based Trade Liberalization Policy ............... 1735

B. Microeconomics-Based Restrictive Immigration Policy .......... 1738

II. The Real Story: Nativistic Racism Plus Economic Interest ............ 1740

A. Nativistic Racism Defined ............................................... 1740

B. Nativistic Racism as a Component of the National lnterest ..... 1744

III. Evidence of Nativistic Racism.................................................... 1745

A. NAFTA's Border Control Plus IIRIRA's

Border Militarization

1. Border Control, Barriers to Entry, and Penalties for Entry

2. Immigrant Smuggling ............................................... 1751

3. Vigilante Justice .................................................... 1756

4. Abuse by Border Patrol .......................................... 1757

B. Lost Jobs and Unprotected Labor ................................ 1760

C. Enhanced Mobility of Professionals ................................. 1764

IV. A Fundamental Reconception of the National Interest................. 1767

A. The Harms of Continuing Past Trends................................ 1768

B. The Inadequacy of Traditional Policy Alternatives ................ 1772

C. Redefining the National Interest ........................................... 1776

Conclusion ..................................................................................... 1778

Copyright $(2004$ California Law Review, Inc. California Law Review, Inc. (CLR) is a Califomia nonprofit corporation. CLR and the authors are solely responsihle for the content of their puhlications.

$\dagger \quad$ J.D., School of Law, University of California, Berkeley (Boalt Hall), 2003; M.P.P., Goldman School of Public Policy, University of California, Berkeley, 2003; B.A., Cornell University, 1998. I thank Lynn Coyle, the first person consulted about this project, for turning to me and saying, "You're a border kid. What do you think?" I also thank Ian Haney López and Donna Maeda for support, encouragement, and invaluable comments on earlier drafts. 


\title{
Border Matters: Redefining the National Interest in U.S.-Mexico Immigration and Trade Policy
}

\author{
Gabriela A. Gallegos
}

U.S.-Mexico immigration and trade policies have developed independently, both pointing to "the national interest" as a guiding principle loosely defined by economic-welfare maximization. Meanwhile, the policies materially interact to affect border peoples by creating or exacerbating such harms as immigrant smuggling, vigilante justice, and civil rights and labor violations. This Comment criticizes the trade-immigration separation and catalogues the resulting border conditions. It argues that the separation of trade and immigration likely stems not simply from economic rationales, but from an understanding of the national interest grounded in nativistic racism and a conception of the nation that excludes border peoples. This Comment offers nativistic racism as an underlying, but dominant, national value that undercuts effective U.S. border policy and maintains the unrealistic separation of trade and immigration policies. Finally, this Comment assesses the likelihood of curing the ills described through traditional legal or policymaking approaches, ultimately calling for a redefinition of the national interest.

\section{INTRODUCTION}

Today is Monday in a U.S.-Mexico border city. At six o'clock in the morning, a truck driver is one of hundreds waiting to cross the border in a traffic line designed to facilitate the swift movement of tariff-free goods from Mexico into the United States. ${ }^{1}$ In his semi-truck, thousands of unfinished pairs of jeans await final assembly and distribution in the United States. Behind his truck sits another truck, a tractor-trailer holding twelve Mexican adults and seven Mexican children. They hide in the dark and pray that they pass through the border-crossing checks undetected. Two lanes over, three nineteen-year-old Mexican women start their weekly

1. In 2003, 4,238,045 trucks crossed the border from Mexico into the United States. See Bureau of Transp. Statistics, U.S. Department of Transportation, Border Crossing: U.S.MEXico Border Crossing DATA tbl.1 (2004), available at http://www.bts.gov/ programs/international/border_crossing_entry_data/us_mexico/pdf/entire.pdf. 
carpool to the public university across the border. ${ }^{2}$ Today, they hope to escape the crossing delays that have made them late for class every day for the past two weeks. Soon after the students cross the bridge, they pass a well-known street corner with groups of men already assembled and waiting for a chance to work. Six day laborers, who earlier had walked across the bridge, climb into the back of a truck whose driver needs help laying the foundation for a new home. ${ }^{3}$

At a crowded downtown bus stop, two streets down, domestic workers wait for buses to take them to the middle-class neighborhoods where they spend their days. Headed south, a "NAFTA man" passes the bus stop as he begins his daily commute into Mexico to the factory he manages. ${ }^{4}$ That evening, the university students again cross the bridge on their way home. The NAFTA man flashes his border-crossing card as he approaches the bridge to return home after a long day. Behind him, a stream of cargo trucks stretches back one mile.

Today at the federal courthouse ten blocks from the bridge, one judge sentenced thirty-seven persons for illegally entering the country. Eight of these persons face mandatory prison time as repeat offenders. In another part of town, Border Patrol agents deposit a group of weather-beaten workers at the immigration-processing center. The workers search the crowded room for a place to rest; a young man offers them his seat. Although he is a U.S. citizen, U.S. immigration authorities detained the young man after he was stopped on his walk home from work and refused to answer inquiries about his citizenship. Back at the courthouse, a group of illegal entrants stand at attention as the judge releases them from custody and explains the likely consequences of a second offense. After twelve days in jail, federal agents drop them at the bridge and watch them walk away.

Sixty-five miles outside of town, a family making its way from Guanajuato, Mexico, to the United States in search of any town needing workers finds shelter from the sun in an old barn. Four miles away, two exhausted and dehydrated Mexican immigrants run through a field as they dodge a rancher's bullets.

2. More than 1,700 Mexicans currently commute from Ciudad Juárez and the interior of Mexico to study at the University of Texas at El Paso (UTEP). Christian Clarke Cásarez, Border Crossing: $A$ Day Trip, Nova Q., Fall 2001, at 55. According to UTEP statistics for 2003-04, Mexican nationals comprise $10.6 \%$ of its 18,542 student population. University of Texas at El Paso, 2003-2004 Facts, at http://www3.utep.edu/aboututep/campusfacts.aspx (last visited Oct. 3, 2004).

3. See Diana Washington Valdez, NAFTA is Mixed Bag for Day Workers, EL PAso Times, June 24,2003 , at $2 \mathrm{~A}$ (describing the working conditions of day laborers).

4. In McAllen, Texas, nearly 2,000 Americans cross the border to Reynosa, Mexico, as "NAFTA men" who manage maquiladoras (assembly plants) on both sides of the border. Cathy Booth Thomas, The Rise of the NAFTA Manager, TIME, June 11, 2001, at 53. 
For border residents, an interdependent economy, transborder commuting, ${ }^{5}$ binational families, ${ }^{6}$ and shared regional histories characterize the borderland culture. The border and the policies that define it distinguish border residents' daily struggles from those of persons living elsewhere in the United States. Every day, all along the southern U.S. border, international crossings with traffic lanes dedicated to North American Free Trade Agreement (NAFTA) ${ }^{7}$ trucks facilitate the movement of tariff-free goods from Mexico to the United States and Canada. At the same time and along the same border, 9,150 Border Patrol agents in white sports utility vehicles with telling green stripes stand guard along the banks of the Rio Grande to prevent the illegal entry of immigrants. ${ }^{8}$ The concurrent increase of free trade and border control implicates two sets of policies: one opens the border for trade; the other shuts it to immigration.

Lawmakers drafted trade and immigration legislation as legally isolated policies, and they remain so. Each policy finds political justification in a particular economics-based theory. In this way, both trade and immigration policies claim to promote the national interest. Though never explicitly defined, legislative history suggests that the nationaI interest refers to a somewhat loose conception of how to maximize domestic economic welfare. ${ }^{9}$ Border peoples ${ }^{10}$ are the consistent losers under this interpretation

5. See generally Timothy Roche, Just Another Day in a Bridge Town, Time, June 11, 2001, at 50 (describing a day in the life of the border towns of Laredo, Texas, and Nuevo Laredo, Mexico). Both Mexicans and Americans operate as transnational commuters as they go to work or to school. Steve Helfand, Comment, Desensitization to Border Violence \& the Bivens Remedy to Effectuate Systemic Change, 12 LA RAZA L.J. 87, 90 (2000-01).

6. See Nestor Rodriguez \& Jacqueline Hagan, Transborder Community Relations at the U.S.Mexico Border: Laredo/Nuevo Laredo and El Paso/Ciudad Juárez, in Caught IN The Middle: Border Communities in an Era of Globalization 88, 96 (Demetrios G. Papademetriou \& Deborah Waller Meyers eds., 2001) (studying transborder communities and the movement of people and goods at the local level).

7. North American Free Trade Agreement, Sept. 13, 1993, art. 102, U.S.-Mex.-Can., 32 I.L.M. 189 (1993) [hereinafter NAFTA].

8. See U.S. Gen. Accounting Office, INS' Southwest Border Strategy: Resource and IMPaCt Issues Remain After Seven Years 2 (2001) [hereinafter GAO, Southwest Border STRATEGY] (evaluating the four-phase Southwest Border Strategy, identifying its primary effect as shifting illegal immigrant traffic, and indicating that more time is needed before the strategy can be evaluated properly).

9. Legal Immigration Act of 1996, S. ReP. No. 104-250, at 2 (1996) ("This committee bill is intended to reform legal immigration to the United States so that it might better serve the national interest."); H.R. REP. No. 103-361(1), at 15-16 (1993) ("[A]pproval of the North American Free Trade Agreement as submitted to the Congress is in the U.S. national interest ....").

10. In this Comment, the term "border peoples" describes Latinas/os, Chicanas/os, Hispanics, Mexican Americans, and Mexicans in the United States (legally or illegally) who reside or work on the U.S. side of the U.S.-Mexico border. This Comment concentrates on U.S. policy; although Mexicans on the Mexico side of the border should count within the concept of border peoples, for the purposes of this Comment, the term "border peoples" refers to those within the official borders of the United States. "Peoples" is used in this description, rather than "residents," "people," or "community," to acknowledge the collective nature of the diverse group based on a common history and culture. While other people along the border may face some of the psychological and economic impacts of trade and 
of national interest. This persistent outcome suggests that economic welfare, termed the national interest, disregards those who are the most immediately and obviously affected by border-dependent policies.

International trade policy and immigration policy operate under different sociopolitical and economic frameworks; however, both claim to maximize wealth in accordance with the national interest. ${ }^{11}$ The conception of the national interest focuses on economic well-being but does not account for the impact on border communities. If these policies do follow a consideration of such border-based harms, the harms are not adequately weighed within the scope of domestic welfare.

The national interest, as defined by the terms of trade and immigration policies, reveals a conception of the border and its peoples based on nativistic racism. Nativistic racism describes the convergence of nativism and racism that underpins the reigning conceptions of American and nation that reinforces racial hierarchy and rejects the interests of border peoples as foreign and undesirable. ${ }^{12}$ This reigning conception fails to recognize border peoples as full participants in the United States. A nativistic racisminformed conception of the nation and the border creates a "false dichotomy" with the "trade/migration separation" found throughout domestic and international laws dealing with the border. ${ }^{13}$ The national interest, then, excludes the histories, current conditions, and concerns of border peoples. ${ }^{14}$

immigration policies, they do not bear the brunt of the burdens and harms described infra, and they fall within the current flawed conception of the national interest, as it relates to the border. Blacks, Asian Americans, and other people of color living on the U.S.-Mexico border likely fall outside the current flawed conception of the national interest, but they do not experience the same harms as border peoples due to their residence and historical roots in the border community.

11. See Julian L. Simon, The Economic Consequences of Immigration 17-20 (2d ed. 1999) (explaining the necessary theoretical disconnect between trade theory and immigration theory in the context of economics).

12. See infra Part Il.A.

13. Kevin R. Johnson, Free Trade and Closed Borders: NAFTA and Mexican Immigration to the United States, 27 U.C. DAvis L. REv. 937, 942 (1994).

14. Rather than include the communities along the 2,000 mile border as part of the national interest, lawmakers view the border through a particular set of nationalist ideals that separate trade and immigration policies and sacrifice border peoples purportedly to promote the U.S. economic interest. Not even the advocacy efforts of an unlikely collection of environmental organizations, political and human rights groups, religious organizations, and others could compel legislators to include any explicit mention of immigration policies in NAFTA. See Frederick W. Mayer, Labor, Environment and the State of U.S. Trade Politics, 6 NAFTA LAW \& Bus. Rev. AM. 335, 336 (2000) (describing NAFTA's opposition as "a new assemblage of advocacy groups"); see also Leah Haus, Integrated Issues: Migration and International Economic Interdependence, in FREE MARKETS, OPEN SOCIETIES, Closed Borders? Trends in International Migration and Immigration Policy in the Americas 85, 94 (Max J. Castro ed., 1999) [hereinafter FreE Markets]; Philip L. Martin, The Mexican Crisis and Mexico-U.S. Migration, in FreE MARKETs, supra, at 133-34 (stating that discussion of illegal immigration was avoided during the NAFTA debate); Alan C. Nelson, NAFTA: Immigration Issues Must Be Addressed, 27 U.C. Davis L. Rev. 987 (1994). 
This Comment argues that the national interest, as applied to and invoked in border-affecting policy, encompasses more than just economic welfare motives. Welfare-maximization purposes undergirded by nativistic racism inform and frame both sets of policies. Part I explains the economic frameworks commonly employed in immigration and trade policymaking and how they relate to each other and purport to center around a profitmaximization interpretation of the national interest. Part II defines the implicit dialogue between the otherwise isolated economic theories supporting existing U.S. trade and immigration policies by suggesting an additional underlying facet of the national interest: nativistic racism. Together, profit motives and nativistic racism inform border policymaking practices. Part III explains the interactions between immigration and trade polices on a practical level and explores their effects on border peoples. Part IV forecasts the effects of continued reliance on a flawed conception of national interest grounded in nativistic racism. Part IV goes on to analyze the problems with piecemeal changes in law and law enforcement as well as the inadequacy of changes to either immigration policy or trade policy. Part IV concludes by proposing that policymakers reconceive the national interest by taking plurality seriously and dismantling the current nativistic racism framework that informs border policy.

I

The Standard Story: Economics-Based Justifications for Trade AND IMMigration Policies

In the mid-1990s, two pieces of legislation dramatically impacted the day-to-day functioning of the U.S.-Mexico border. In 1993, Congress passed legislation to implement NAFTA. ${ }^{15}$ On January I, 1994, NAFTA created a "free trade zone" in the United States, Canada, and Mexico to facilitate trade and investment. ${ }^{16}$ The objectives of the agreement include eliminating barriers to trade in goods and services, promoting conditions of fair competition, improving investment opportunities, and protecting intellectual property. ${ }^{17}$ Building on the existing Canada-U.S. Free Trade Area Agreement, ${ }^{18}$ NAFTA promised domestic economic returns and sustained growth. ${ }^{19}$

Also in 1993, now-Congressman Silvestre Reyes (D-TX) launched Operation Hold-the-Line (previously named Operation Blockade) in El

I5. The North American Free Trade Agreement Implementation Act, Pub. L. No. 103-I82, I07 Stat. 2057 (1993)

I6. U.S. Gen. Accounting Office, North American free Trade Agreement: U.S. EXPERIENCE With ENVIRoNMENT, Labor, and INVESTMENT Dispute SETTlement Cases 3 (2001).

17. NAFTA, supra note 7.

18. Free Trade Agreement, Jan. 2, 1988, U.S.-Can., 27 I.L.M. 281 (1988).

19. H. ReP. No. 103-361, at 8-9 (I995) (outlining the benefits of free trade with Mexico and Canada). 
Paso, Texas. ${ }^{20}$ The strategy sent 400 of El Paso's 650 Border Patrol agents to the banks of the Río Grande; agents repaired fences and lined a 20-mile stretch of the border. ${ }^{21}$ Subsequent border-control initiatives soon followed the Operation Hold-the-Line strategy of border fortification: Operation Gatekeeper in San Diego, California, Operation Safeguard in Nogales, Arizona, and Operation Rio Grande in McAllen and Laredo, Texas. ${ }^{22}$ Federal legislation soon followed, expanding border-control initiatives. In 1996, Congress passed the Illegal Immigration Reform and Immigrant Responsibility Act (IIRIRA), ${ }^{23}$ which ratified the "Southwest Border Strategy" and included extensive reforms that focused in large part on the prevention and punishment of illegal immigration. ${ }^{24}$ The congressional Commission on Immigration Reform articulated two goals for the 1996 reforms in IIRIRA (originally called the Immigration in the National Interest Act of 1995): "(1) restoring credibility to the U.S. system of enforcement against illegal migration, and (2) setting priorities for legal immigration that are in accord with the national interest." 25

To serve the national interest in the immigration-reform context, lawmakers sought to match migration to the needs of the U.S. economy. To do so in the trade liberalization context, lawmakers needed to facilitate the free movement of goods and capital to strengthen the U.S. economy. Lawmakers justified both trade and immigration policies with economic rationales and promised gainful returns. The national interest, however, is rooted in justifications deeper than economic prosperity alone. The model of economic prosperity that characterized lawmakers' conception of the national interest excludes border peoples and is informed by narrow conceptions of nation and the national interest.

\section{A. Macroeconomics-Based Trade Liberalization Policy}

Trade and immigration law and policies draw largely upon separate economic theories, and they each operate in isolation from the other. In the context of U.S.-Mexico trade relations, this split allows for an agreement

20. See David Spener, The Logic and Contradictions of Intensified Border Enforcement, in THE Wall Around the West 115, 118 (Peter Andreas \& Timothy Snyder eds., 2000). At the time of Operation Hold-the-Line, Reyes served as Chief of the El Paso Sector of the Border Patrol. His term as chief followed that of Chief Musegades, who left his post following the settlement of a class-action suit against the Border Patrol for civil and human rights violations. See Murillo v. Musegades, 809 F. Supp. 487 (W.D. Tex. 1992); infra Part 1ll.A.4.

21. Spener, supra note 20, at 118.

22. Peter Andreas, Border Games 97 (2000).

23. 1llegal Immigration Reform and Immigrant Responsibility Act of 1996, Pub. L. No. 104-208, 110 Stat. 3009-546 (1996) (codified as amended in scattered sections of 8 U.S.C. and 18 U.S.C.).

24. For further description of the implementation of the Southwest Border Strategy and the increases in Border Patrol agents patrolling the southwest border, see GAO, Southwest Border STRATEgY, supra note 8, at 7-10.

25. Lamar Smith \& Edward R. Grant, Immigration Reform: Seeking the Right Reasons, 28 ST. MARY's L.J. 883, 891 (1997) (footnote omitted). 
designed to promote economic integration to ignore the fundamental and historical social and economic pressures of migration. ${ }^{26}$ However, the microeconomics-based theories underlying immigration policies and the macroeconomics-based theories underlying trade policies collide in practice, thus yielding a peculiar set of legally isolated U.S.-Mexico relations policies that simultaneously open and close the border. ${ }^{27}$ Economic frameworks for trade and immigration both deal with workers, but trade theory assigns each worker a permanent address, while traditional immigration theory accounts for the push and pull effects on workers of developing and developed nations, respectively. ${ }^{28}$

The theory of comparative advantage led economists to recommend trade liberalization as a mutually beneficial policy for countries participating in NAFTA - Canada, Mexico, and the United States. ${ }^{29}$ NAFTA proponents promised that the trilateral agreement would increase economic welfare in each of the three countries by removing additional burdens to the trade of goods that originated in North America and eventually curb worker migration by strengthening domestic economies. ${ }^{30}$ ln other words, while other countries set tariffs and investment restrictions to maximize their overall wealth, encourage domestic investment, and protect domestic industries, under NAFTA, Canada, Mexico, and the United States would reduce and then eliminate tariff and nontariff trade barriers to enable the free mobility of goods and services between countries. ${ }^{31}$ Trade, unobstructed by tariffs and other barriers, would benefit both countries by

26. U.S.-Mexico Migration Panel, Mexico-U.S. Migration: A Shared Responsibility 11 (2001).

27. See Johnson, supra note 13, at 954-71; see also Rodriguez \& Hagan, supra note 6, at 88-115 (studying the institutional relations between the border communities of Laredo-Nuevo Laredo and El Paso-Ciudad Juárez); Hania Zlotnik, Policies and Migration Trends in the North American System, in International Migration, Refugee Flows and Human Rights in North America 81, 99 (Alan B. Simmons ed., 1996) ("Thus, although NAFTA cschews almost any mention of migration, it fosters various types of exchanges between Canada, Mexico, and the United States, exchanges that are unlikely to occur without increasing the transnational mobility of people.").

28. The push-pull model of immigration is "constructed around 'factors of expulsion' (economic, social, and political hardships in the sending countries) and 'factors of attraction' (comparative economic and political advantages in the receiving countries)." Alejandro Portes \& RubÉN G. Rumbaut, Immigrant America 271 (2d ed. 1996).

29. See, e.g., Howard F. Chang, Migration as International Trade: The Economic Gains from the Liberalized Movement of Labor, 3 UCLA J. INT'L L. \& FOREIGN AFF. 371, 372 (I998-99) (arguing for a policy that liberalizes immigration and taxes immigrant workers by applying trade principles to immigration law, thereby prioritizing distributive justice for natives).

30. In the case of two countries, $A$ and $B$, both countries will benefit if each country specializes in producing goods of which they are the most efficient producer. If Country A and Country B each specialize their production according to their comparative advantage and then trade goods without the additional burden of tariffs and other prohibitive transaction costs, both countries will benefit from each other's efficiency.

31. NAFTA purportedly exists as "the best means for attaining the agreed objectives of a vigorous economic relationship, maintaining sustained growth, and expanding trade and investment between [Mexico and the United States]." H.R. REP. 103-361, at 5. 
allowing them to buy from the other what they cannot as efficiently produce. $^{32}$ For the United States and Mexico, the advantages were clear: the United States has abundant capital resources and Mexico has inexpensive labor.

Effective liberalized trade requires that each country's resources stay put. ${ }^{33}$ Mexico's comparative advantage in cheap labor fails the effectivetrade test if all or most of its labor force moves north of the border. If legislators assumed that Mexico's advantage was inexpensive labor, then the intensified border-control policies of 1996 make perfect economic sense: Mexico, without cheap labor, may become a less-attractive trading partner. Therefore, the United States should do all it can to keep Mexican workers in Mexico. Trade theorists, in isolating tradable goods from the movement of human capital, assert that "[c]onsumers do not obtain the same sort of gains from the international movement of people as they do from international exchange of goods .... And the 'explanation' of why people move is different from the explanation of why goods move." 34 Accordingly, trade theory is "necessarily silent about migration"; it does not consider labor to be a tradable resource. ${ }^{35}$

If labor were treated as a tradable factor of production, free trade conceivably would "imply free movement of people across borders." ${ }^{36}$ One could imagine that, under a market-driven system of trade, the free movement of people across borders would lead to the greatest efficiencies in production in the long run. ${ }^{37}$ Workers would relocate to fill employers' needs, and industries would settle into the locations most amenable to their entry. But trade operates under an economic theory separate and distinct from that of immigration: trade benefits countries, but migration benefits the migrant. Free trade, rather than including immigrants in the profitmaximization calculus, asks countries to specialize production using resources that are domestically available. It separates goods from the people that produce them and treats labor as an immobile factor of production. An enhanced trade relationship between two bordering nations, one developed and one underdeveloped, while convenient, cannot reasonably exclude the possibility of labor mobility in its cost-benefit analysis.

32. See Chang, supra note 29, at 371-72; Martin, supra note 14, at 127-28 (describing the rigorous economic modeling and forecasting undertaken as part of the pre-NAFTA evaluation process).

33. Chang, supra note 29 , at 372.

34. Simon, supra note 11 , at 17 .

35. Id.

36. Chang, supra note 29 , at 372.

37. See id. (applying principles of free trade to labor services); Howard F. Chang, Immigration and the Workplace: Immigration Restrictions as Employment Discrimination, 78 CH1.-KENT L. REV. 291, 297-98 (discussing the possibility of unrestricted labor mobility in world labor markets). 


\section{B. Microeconomics-Based Restrictive Immigration Policy}

Trade theory leaves the explanation of why people move to immigration theory, which examines the international movement of workers, families, and refugees. The simplest economic explanation for the pull of migration holds that the expected gains of migration outweigh the expected costs of migration, including transaction costs. ${ }^{38}$ In developed countries, employer demand and the promise of higher wages pulls in immigrants; in less-developed countries, political and economic hardships push immigrants out. ${ }^{39}$ In the case of Mexico and the United States, transaction costs of immigration include the use of $\operatorname{coyotes}^{40}$ and a risk calculus that considers potential federal prosecution, incarceration, ${ }^{41}$ and possible death. ${ }^{42}$ However, this liberal economic view, which analyzes migration as a spontaneous market process that will restore equilibrium in the event of an imbalance in the labor supply and demand, fails to recognize and account for changes in migration patterns and the changing demographic characteristics of migrants themselves. ${ }^{43}$ It also fails to explain why immigrants neither originate from the poorest countries nor comprise the poorest among their countries of origin. ${ }^{44}$

U.S. policy treats migrants as individual economic actors: workers move to improve their own lives and those of their dependants, not to

38. See Simon, supra note 11 , at 15 . For a review of theories of international migration, see Douglas S. Massey et al., Beyond Smoke and Mirrors: Mexican lMmigration in an Era of ECONOMIC INTEGRATION 7-23 (2002).

39. Id.

40. A coyote is a professional smuggler of undocumented immigrants. See ANDREAS, supra note 22, at 37; see also Terry McCarthy, The Coyote's Game, Time, June 11, 2001, at 56.

41. In 2003 alone, there were 15,266 federal criminal filings for felony immigration violations. Of these, $68.1 \%$ of the cases were filed in the five federal district court jurisdictions on the border: Texas Westem, Texas Southern, Arizona, Ncw Mexico, and California Southern. U.S. District Courts, Judicial Caseload Profile Report: 2003 Civil and Criminal Felony Filings by Nature of Suit and Offense, available at http://www.uscourts.gov/cgi-bin/cmsd2003.pl.

42. Migrant deaths may result from environmental causes, such as drowning and heat exposure, and some may be attributed to vehicular manslaughter and murder. See infra Part 111.A.3 (discussing vigilante justice). In fiscal year 2000, the Border Patrol recorded 135 immigrant deaths from exposure to heat and 92 deaths from drowning. BELINDA I. REYES ET AL., HOLDING THE LINE?: THE EFFECT OF RECENT Border BuILD-up on UNAUThorized IMMIgRation 70 (2002). Between 1985 and 1998, there were 3,600 documented deaths during border crossings. KARL EschBaCh, JaCQUeLINE HaGaN \&

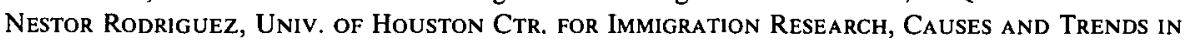
Migrant Deaths Along the U.S.-Mexico Border, I985 - 1998 (200I). Between 1993 and 1997, there were possibly 1,034 undocumented deaths during border crossings. Karl Eschbach et al., Death at the Border, 33 InT'L Migration Rev. 430-40 (1999); see also Pamela Colloff, The Battle for the Border, Texas Monthly, Apr. 2001, at 99 ("During the past two years, Mexicans passing through this corner of South Texas have been the targets of six shootings. Two of the victims were killed. All of them were shot in the back."').

43. See Haus, supra note 14 , at 86

44. Id. 
increase the destination country's overall economic welfare. ${ }^{45}$ Responding to this understanding of immigration as a microeconomic process, the United States has crafted its immigration policy by providing incentives or disincentives for immigration depending on the country's need for cheap labor. In this way, the United States has chosen to maximize domestic economic welfare by controlling the individual choices of would-be immigrants. For example, from 1917 to 1922 , Congress responded to the needs of domestic agricultural employers in the Southwest by implementing the first temporary-worker program. ${ }^{46}$ To drive Mexicans back to Mexico during the Depression, the U.S. government denied Mexican laborers welfare benefits. The Bracero program, which operated in the 1940s and 1950s, responded to wartime calls by domestic agricultural employers for a Mexican fieldworker labor force. ${ }^{47}$ In the late 1950s, the Immigration and Naturalization Service reasserted control over the border and expelled illegal migrant workers by initiating Operation Wetback, ${ }^{48}$ the "first large-scale, systematic implementation of military strategy and tactics by the INS against Mexican immigrants." 49

Although free trade and immigration policies fail to account for each other, such policies interact in substantial and important ways when put into practice. Ultimately, both purport to maximize economic welfare for the United States under the pretext of the national interest. Trade theory seeks to eliminate barriers to allow the market to naturally find equilibrium through specialization of production and free movement of goods. Immigration theory allows for adjustments in obstacles and incentives to migration for the purposes of protection or supplementing the American workforce. The failures of trade and immigration theories to meaningfully interact coupled with the consistent and material losses that border peoples suffer in the course of the intermingling of the two policies, suggest that there is an additional dimension to the national interest. The following Part introduces nativistic racism and posits that it functions as an additional component of the current conception of the national interest and an important driving force behind U.S.-Mexico border policies.

45. See Saskia Sassen, Transnational Economies and National Migration Policies, in FreE MARKETS, supra note 14 , at $7,13$.

46. See Gilbert Paul Carrasco, Latinos in the United States: Invitation and Exile, in Immigrants Out! The New Nativism and the ANTi-Immigrant Impulse in the United States 190, 193 (Juan F. Perea ed., 1997).

47. See KitTy Calavita, Inside the State 18-41 (1992) (chronicling the Bracero program ani subsequent immigration control policies).

48. See id. at 49-6I (describing Operation Wetback as a political success and replete with abuse by Border Patrol that went unchecked).

49. Timothy J. Dunn, The Militarization of the U.S.-Mexico Border, I978 - I992 52 (1996) (tracing U.S. immigration and drug enforcement policies and practices along the U.S.-Mexico border); see also Juan F. Perea, A Brief History of Race and the U.S.-Mexican Border: Tracing the Trajectories of Conquest, 51 UCLA L. REv. 283, 303-10 (2003) (discussing the cyclical and exploitive use of temporary Mexican workers in the United States). 


\section{II}

\section{The Real Story: Nativistic Racism Plus Economic Interest}

Economic considerations alone cannot justify the facial and substantive exclusions of immigration from trade policy and vice versa. The isolation of the two policies yields consequences that consistently and negatively affect border peoples. Border peoples endure treatment as a subjugated class that, regardless of legal status, never attains full citizenship in the eye of the national imagination. ${ }^{50}$ The losses border peoples suffer, and the quality of those losses, reveal a conception of the national interest grounded in nativistic racism. ${ }^{51} \mathrm{By}$ adding nativistic racism to the nationalinterest calculus, violent border conditions comport with economic disadvantages.

\section{A. Nativistic Racism Defined}

Nativism encompasses a type of nationalism that defines American in contrast to un-American and foreign. Nativists commonly express concentrated antagonism toward a group within the United States based on that group's perceived status as alien and contrary to an American way of life. ${ }^{52}$ Historically, nativists have believed "that some influence originating abroad threatened the very life of the nation from within." ${ }^{.53}$ Racism in the United States historically and currently operates to disadvantage nonwhite groups in systemic, intentional, or de facto ways. ${ }^{54}$ Grounded in both

50. For a history of the U.S.-Mexico border region, see gencrally Perea, supra note 49 (examining the border and explaining deficiencies in Latina/o political power through "trajectories of conquest").

51. See infra Part III.

52. John Higham, a pathbreaking historian of American culture and immigration, defines nativism:

Nativism ... should be defined as intense opposition to an internal minority on the ground of its foreign (i.e. "un-American") connections. Specific nativistic antagonisms may, and do, vary widely in response to the changing character of minority irritants and the shifting conditions of the day; but through each separate hostility runs the connecting, energizing force of modern nationalism. While drawing on much broader cultural antipathies and ethnocentric judgments, nativism translates them into a zeal to destroy the enemies of a distinctively American way of life.

John Higham, Strangers in the Land: Patterns of American Nativism I860-I925 4 (1974).

53. Id. Nativism, and the concept of native in the context of nativism, considers white AngloSaxon Protestants as the norm. At different points in history, nativism has been expressed as antiCatholic, anti-Irish, anti-Italian, and anti-immigrant sentiment. See generally id. (tracing nativism from 1860 through I925); Berta Esperanza Hernández-Truyol, Newcomers and Nativism: A Human Rights Model for the Twenty-First Century, 23 FORDHAM URB. L.J. 1075, I083-94 (providing a brief history of nativism since the early 1800s); Kevin R. Johnson, The End of "Civil Rights" as We Know It? Immigration and Civil Rights in the New Millennium, 49 UCLA L. REv. 1481, 1485-90 (describing the American history of racialization of immigrants and the social assimilation of German, Irish, Jewish, and Italian immigrants).

54. I rely in this Comment on a recent redcfinition of racism: "action arising out of racial common sense and enforcing racial hierarchy." IAN F. HANEy López, Racism on Trial: The Chicano FIght FOR Justice 127 (2003). Racism as common sense incorporates widely expressed 
historical and material realities, nativistic racism leads individuals and societies to implicitly assent to the basic tenet of white supremacy and its perpetuation through policies and practices that consistently overlook, disadvantage, and attempt to weaken communities of color.

The term "nativistic racism" describes the symbiotic character of nativism and racism, especially as related to the dominant conception of the national interest. More specifically, the term "signifies that both nativism and racism are mutually constitutive of the other and operate in tandem to preserve a specific conception of the nation." 55 Nativistic racism in the United States requires an American to be white, and it precipitates the unconscious notion that the nation should protect and serve whites within its borders.

The defining margins of white as a socioracial group have changed over time. ${ }^{56}$ However, whites have consistently defined the legal, political, and social norms for American equality. ${ }^{57}$ More importantly, positional privilege defines whites within the United States. Exercising this privilege, whites narrowly circumscribe the term "American" to refer to only people of Anglo and non-Anglo European descent who have successfully assimilated. "American" then becomes a white-majority term of selfidentification that perpetuates and exemplifies racial hierarchy. ${ }^{58}$ Despite the constantly morphing demographics that make whites the minority socioracial group in some areas of the country, whites persist as the group whose power defines the margins of American citizenship. Whites propose national policies in colorblind and so-called economic terms, all the while

social norms and routine practices that underpin racial hierarchy. Id. Common sense racism has in earlier writings been termed "institutional racism." Id. at 132 .

55. Robert S. Chang \& Keith Aoki, Centering the Immigrant in the Inter/National Imagination, 85 Calif. L. Rev. 1399, 1401 (1997), 10 LA RAZA L.J. 313, 315 (1998).

56. See Ian F. Haney López, White by Law: The Legal Construction of Race (1996); James R. Barrett \& David Roediger, In Between Peoples: Race, Nationality, and the "New Immigrant" Working Class, in AGAinst ExCEPTIONALISM 181 (Rick Halpern \& Jonathan Morris eds., 1997). See generally HighaM, supra note 52 (providing a history of early American opposition to immigrants); Robert S. Chang, Disoriented: Asian-Americans, Law, and the Nation-State 18-20 (1999) (examining race and law, borders, and national American identity as they related to Asian Americans). Mexican Americans, in particular, have been the subject of shifting racial identities in the legal sense. See, e.g., HANEY LÓPEZ, WhITE BY LAw, supra. Without delving into the historical realities that explain the shifting status, in this Comment, the term "white" does not include border peoples.

57. See HANey López, White By Law, supra note 56, at 49-77; Juan F. Perea, Buscando América: Why Integration and Equal Protection Fail to Protect Latinos, 117 Harv. L. Rev. 1420, 1446-54 (2004). See generally HANEy LóPEz, RaCISM ON TRIAL, supra note 54 (examining Mexican American self-identity in the context of racist legal institutions).

58. See generally HANEY LÓPEZ, WhITE BY LAW, supra note 56, at 61, 249; Barbara Flagg, "Was Blind, But Now I See": White Race Consciousness and the Requirement of Discriminatory Intent, 91 Mich. L. REv. 953, 969-70 (1993) (explaining the white transparency and the tendency of whites to view themselves as neutral decisionmakers); Trina Grillo \& Stephanie M. Wildman, Obscuring the Importance of Race: The Implication of Making Comparisons Between Racism and Sexism (Or Other -Isms), 1991 DukE L.J. 397, 405 (1991) ("Being the norm allows white people to ignore race, except when they perceive race (usually someone else's) as intruding on their lives."). 
perpetuating and assenting to nativistic racism as a hallmark American value.

While lawmakers at times consciously manifest nativistic racism, this Comment treats nativistic racism as an unconscious, group-based phenomenon that informs current policies and their applications. ${ }^{59}$ A national self-identity based on nativistic racism pervades policymaking and shapes the regulation and enforcement, or lack thereof, of laws affecting border peoples. ${ }^{60}$ Ian Haney López terms the phenomenon of unintentionally applying laws discriminately as common sense ${ }^{61}$ Common sense theory helps explain decisions that reveal often-widespread social understandings. ${ }^{62}$ Nativistic racism helps to explain both the social understandings that inform policy decisions and the failure of policymakers to adequately consider the well-being of border peoples in the calculus of the national interest. With a nativistic racist conception of the national interest, the border becomes a problematic feature of the nation-state.

U.S. nationalism necessitates a Iine of demarcation between American and un-American, and border peoples challenge this line because their cultures, families, languages, problems, and economies spread across both sides of the Río Grande. ${ }^{63}$ U.S.-Mexico border peoples test the national imagination by tolerating ambiguities in the definitions of self and community that deviate from the traditional American understanding of nationalism. ${ }^{64}$ The national imagination informed by nativistic racism perceives

59. Cf. Charles R. Lawrence III, The Id, the Ego, and Equal Protection: Reckoning with Unconscious Racism, 39 STAN. L. REv. 317, 322 (1987) (arguing that racism is a largely unconscious phenomenon arising from the fact that "Americans share a common historical and cultural heritage in which racism has played and still plays a dominant role."). In not imputing intent to policymakers on nativistic racism grounds, 1 offer the following personal example: My genealogy traces back eight generations to the same location where I was raised: El Paso, Texas. My family has been tied to the region since before Texas was part of the United States and before Texas was a country. But I routinely field the question, "Where are you from?" My answer, "El Paso, Texas," generally yields the phrase often heard by foreign-perceived persons in the United States: "Yes, but where are you from?" While the question is often meant only to reflect well-intentioned curiosity, its underlying nativistic racism connotation offends.

60. Some of the harms detailed in this Comment, such as those resulting from vigilante justice, illustrate the effects of conscious nativistic racism. Unconscious nativistic racism informs the policies that create the conditions for such acts of vigilantism. See infra Part III.A.3.

61. See Haney LóPEz, Raclsm on Trial, supra note 54, at 109-13. Common sense theory explains that racist social understandings are so pervasive that their truth is taken for granted and their application is unconscious. Id.

62. Id. at $1 \mathrm{I} 0$.

63. Border peoples challenge traditional understandings of American in formal and informal ways. In 1999, for example, the South Texas border town of El Cenizo passed two ordinances: one adopted Spanish as the predominant language for city business and the other-the "Safe Haven" ordinance-prohibits the City's elected officials from inquiring as to or disclosing the immigration status of any resident. María Pabón López, The Phoenix Rises from El Cenizo: A Community Creates and Affirms a Latino/a Border Cultural Citizenship Through Its Language and Safe Haven Ordinances, 78 DENV. U. L. REV. I017 (200I).

64. See generally Gloria AnZaldúa, Borderlands/La Frontera 77-80 (1987) (theorizing the border as a separate cultural and imaginary space). 
border peoples as other and foreign because they refuse to adhere to the political boundary in any conventional or acceptable manner. ${ }^{65}$

Border policies informed by nativistic racism respond to the fear "that the border region . . . can erode the hegemony of the privileged center by denationalizing and deterritorializing the nation/state." ${ }^{66}$ With whites as the quintessential American norm and national borders aiding in the preservation of that norm, border peoples fall outside of the norm and challenge it. To be sure, border peoples are said to believe in three cultural entities: Mexico, the United States, and the border areas where Mexico meets the United States. ${ }^{67}$ The region that border peoples inhabit is often termed "el tercer país," or the third country. The nickname works: border peoples technically live within the physical boundaries of the United States, and yet they fall outside of the national interest.

The demographics of border populations also contribute to the understanding of the border region as a separate entity. In the United States, Latinas/os make up an estimated $12.5 \%$ the population; however, in twenty of the twenty-four border counties, Latinas/os comprise the majority of the population. ${ }^{68}$ Perhaps the border falls outside most Americans' frames of

65. John S, Robey explains the cultural connections between U.S. and Mexican border-area residents:

The river has always been an artificial border in many respects. The typical Hispanic U.S citizen that residcs in Brownsville has much more in common with the culture of his neighbor in Matamoros than he does with his fellow countryman in Alaska .... [And] the typical resident of Matamoros is much more comfortable with his compadre in Texas than he is with the indigenous peoples of the Yucatan

John S. Robey, Civil Society and NAFTA: Initial Results, 565 Annals Am. ACAD. Pol. \& Soc. Sci. 113, 123 (1999). Oscar J. Martinez also notes how the lives of "borderlanders" challenge the national norm:

In truth [the border] is a world apart - a third very unsovercign nation, not wholly Amcrican and not quite Mexican either, with its own customs, mores, values, and even its own language, Spanglish. Family ties, religious roots, and economic interdependence knit the border region in both countries together to the point that [U.S. border cities] have more in common with their sister towns in Mexico than they do with most of the United States.

Oscar J. Martínez, Border People: Life and Society in the U.S.-Mexico Borderlands 20-21 (1994) (quoting $A$ World Apart, NEwsweEK, Apr. 11, 1986, at 36) (alteration in original).

66. Alejandro Lugo, Reflections on Border Theory, Culture, and the Nation, in BORDER THEORY: The Limits of Cultural Politics 43, 45 (Scott Michaelsen \& David E. Johnson eds., 1997).

67. See Robey, supra note 65 , at 123 .

68. U.S. Census Bureau, GCT-P6. Race and Hispanic or Latino: 2000, available at http://factfinder.census.gov/home/saff/main.html?_lang=en (last visited Sept. 22, 2004) (to find demographic data, select "Pcople," then use the search tools to narrow the request by country and state). In each of the twenty-four border counties, Latinas/os make up more than double the national average of $12.5 \%$ of the population. Id. In Arizona, Cochise County: 30.7\%; Pima County: 29.3\%; Santa Cruz County: $80.8 \%$; Yuma County: 50.5\%. Id. In California, Imperial County: $72.2 \%$; San Diego County: 26.7\%. Id. In New Mexico, Doña Ana County: 63.4\%; Hidalgo County: 56.0\%; Luna County: $57.7 \%$. Id. In Texas, Brewster County: 43.5\%; Cameron County: $84.3 \%$; Culberson County: 72.2\%; El Paso County: 78.2\%; Hidalgo County: $88.3 \%$; Hudspeth County: $75.0 \%$; Jeff Davis County: 35.5\%; Kinney County: 50.5\%; Maverick County: 95.0\%; Presidio County: $84.4 \%$; Starr County: 97.5\%; Terrell County: 48.6\%; Val Verde County: 75.5\%; Webb County: $94.3 \%$; Zapata County: $84.8 \%$. Id. 
reference, or perhaps the majority-Latina/o region blurs and defies the line of demarcation necessary for dominant ideas about what the terms "nation" and "American" mean. Both are informed by nativistic racism.

\section{B. Nativistic Racism as a Component of the National Interest}

With nativistic racism operating below the surface of economic justifications for immigration and trade policies, the national interest transforms from an undefined, loosely economic term to a narrowly circumscribed explanation of what it means to be American. Under this reading, the national intcrest centers on a specific understanding of nation. A national conception based on nativistic racism informs policy decisions that in effect hold that Mexicans who stay on the other side of the border are useful tools of production while Mexicans on this side of the border should be punished, removed, or killed as criminals. ${ }^{69}$ When applied to the border region and its ambiguities, the policies extend to all border peoples. Latinas/os on the U.S. side of the border become indistinguishable "others" in the national imagination who fall outside of the national interest.

For example, in United States $v$. Brignoni-Ponce, the Supreme Court held that "[ $t]$ he likelihood that any given person of Mexican ancestry is an alien is high enough to make Mexican appearance a relevant factor" for the Border Patrol to consider in stopping a vehicle. ${ }^{70}$ In the dissenting opinion of an appeal to the Fifth Circuit over a Fourth Amendment vehicle-stop case, Judge Wiener described this stripping of Fourth Amendment protections for persons near the U.S.-Mexico border as "joining Korematsu, Dred Scott, and even Plessy on the list of our most shameful failures to ... defend[] constitutional civil liberties against the popular hue and cry that would have us abridge them." "7l Judge Wiener criticized the federal judiciary for its role in rolling back the rights of border peoples. ${ }^{72}$ Even though Mexican appearance alone does not justify a stop by the Border

69. See generally Benjamin Alire Sáenz, Just Another Mexican (Apr. 20, 2004) (unpublished manuscript, on file with the California Law Review) (examining the fatal shooting of a Mexican national by Border Patrol).

70. 422 U.S. 873, 886-87 (1975); Alfredo Mirandé, Is There a "Mexican Exception" to the Fourth Amendment?, 55 FLA. L. REv. 365 (2003) (tracing Fourth Amendment jurisprudence as it relates to Mexicans and Mexican Americans); see also United States v. Arvizu, 534 U.S. 266 (2002) (upholding "totality of the circumstances" test in reasonable-suspicion determination hy Border Patrol agents); United States v. Ojebode, 957 F.2d 1218 (5th Cir. 1992) (holding that border searches based on ethnicity are constitutional). Although this ruling required that Mexican appearance accompany some other factors to establish reasonahle suspicion of illegal status, in practice the rule is difficult to apply. Few Mexican-appearing Latina/o, Chicana/o, and Mexican American lifelong border dwellers have escaped being stopped by the Border Patrol.

71. United States v. Zapata-lbarra, 223 F.3d 281, 282 (5th Cir. 2000) (Wiener, J., dissenting) (citations omitted).

72. Id. at 281-82 ("[T]he fabric of our society suffers significantly more harm by sacrificing the right of all the people-including those near the Mexican border-to the constitutional protections of the Fourth Amendment than it gains from the apprehension of a few more illegal immigrants ...."). 
Patrol, the messages are clear: if you look Mexican, you are probably illegal, you do not belong, you are not American, and you are not part of the national interest. Border peoples live with the expectation that their legal status requires constant verification. ${ }^{73}$

While never specifically defined by policymakers, their view of the national interest is inextricably attached to the desire to improve and enrich the domestic economy. Through the lens of nativistic racism, service of the national interest requires the pursuit of economic prosperity and growth but narrows this pursuit by disregarding the ensuing harms to border peoples and benefiting only those Americans that fit within a particular conception of the national identity. In this environment, legal and political decisions undervalue the quality of life of border peoples while maintaining racial hierarchy. Trade and immigration policies have created certain categories of persons and assigned value to them, and laws continue to be drafted and enacted based on a particular national identity that excludes, criminalizes, and dehumanizes border peoples. In the name of the national interest, trade and immigration policies interact to sacrifice the land, resources, and civil and human rights of border dwellers. The next Part traces a pattern of trade and immigration policies informed by nativistic racism, and it describes their effects on border communities.

\section{III}

\section{EvidenCE of NATIVISTIC RACISM}

The unnatural bifurcation of trade and immigration illustrates the clash between the so-designed national interest and the interests of border peoples. Policies, such as NAFTA and IIRIRA, which are justified through economic theories and purport to increase domestic wealth, in the end harm the land and resources of the border area while impinging upon the civil rights of the majority of border peoples. Nativistic racism helps to explain the pattern of policies that reinforce racial hierarchy and situate border peoples in the position of disaffected supplicants outside the scope of the national interest.

The border militarization required by a liberalized trade regime that fails to address migration creates problems that uniquely impact the border.

73. The Brignoni-Ponce decision could have come much closer to legitimating bald-faced racial profiling by allowing the appearance of Mexican ancestry alone to constitute reasonable suspicion. Still, because it remains as one legitimate factor among others, and because of the difficulties in proving its functional isolation in the practice of stopping and questioning by the Border Patrol, the ruling comports with and advances nativistic racism in the United States. Border peoples tolerate a notfully-American status to accommodate the country's so-called interest in apprehending illegal entrants. See also United States v. Montero-Camargo, 208 F.3d 1122, 1131-35 (9th Cir. 2000) (calling into question the applicability of Brignoni-Ponce given the size of the Hispanic population in border states and throughout the country). See generally Susan Martin \& Philip Martin, International Migration and Terrorism: Prevention and Protection, 18 GEo. 1MMIGR. L.J. 329 (2004) (criticizing profiling as a mechanism of terrorism prevention). 
Specifically, U.S. policies often sacrifice the civil and human rights of border peoples by punishing border crossers and incentivizing immigrant smuggling and acts of vigilantism. Meanwhile, line workers lose jobs and grow more vulnerable to labor violations as foreigners seeking to invest in the United States gain free entry and reentry, because they make no attempt to become American. Border peoples remain low on the policymaking priority list unless they can pay for the privilege of fitting into the national interest.

This Part examines the practical interaction of free trade and restrictive immigration policies to make the case that nativistic racism plays a significant role in the reigning conception of the national interest. It begins by outlining harms resulting from border policies premised upon a flawed conception of the national interest. It details four conditions resulting from the combination of border militarization and free trade: tightened immigration controls and penalties for illegal entry, immigrant smuggling, vigilante justice, and abuse by Border Patrol. Then, it looks at NAFTA specifically and examines its how its labor side agreement disregards border peoples. This Part concludes by discussing the one area in which NAFTA and IIRIRA easily agree: professionals and investors may freely enter the United States. These three different sets of consequences all evidence the current flawed conception of the national interest and demonstrate its effects on border peoples.

\section{A. NAFTA's Border Control Plus IIRIRA's Border Militarization}

NAFTA's text recognizes "the need to ensure border security and to protect the domestic labor force and permanent employment in their respective territories." 74 Aside from this broad statement, NAFTA provides neither guidance nor justifications for countries to ensure border security. It only discusses border security in the context of temporary entry for business persons and facilitates cross-border capital investments. NAFTA's broad statement superficially recognizes the importance of immigration policy to free trade, but the agreement never moves beyond this acknowledgement to consequential interaction.

IIRIRA's two goals of restoring credibility to illegal immigration enforcement and setting immigration goals in line with the national interest speak to a different goal, a symbolic goal. ${ }^{75}$ The goals interrelate because setting priorities for legal immigration necessarily entails defining who will be subject to the increased enforcement against illegal immigration. While

74. NAFTA, supra note 7, at art. 1601.

75. See Smith \& Grant, supra note 25 , at 891 (identifying the underlying goals of immigration reform as articulated by the Commission on Immigration Reform). In the 1990s, the borderenforcement strategy was more a response to domestic fears over immigration than a response to actual increases in immigration. MASSEY ET AL., supra notc 38, at 103 . The imagery of a policed bordcr helped to calm those fears. Id. at 101-04 (explaining the symbolic politics of border control) 
IIRIRA includes provisions relating to a wide range of immigration topics, from restrictions on public benefits to the removal of administrative review for asylum-seekers denied sanctuary, it concentrates largely on illegal immigration punishment and prevention. ${ }^{76}$ The Southwest Border Strategy began blockading the border just two years after NAFTA mentioned the need for border security.

\section{Border Control, Barriers to Entry, and Penalties for Entry}

The IIRIRA takes illegal immigration control in "bold new directions, particularly in the areas of deterring illegal migration to the United States, and of apprehending, detaining, and removing those who have illegally entered our country."77 In so doing, IIRIRA treats the southern border with Mexico as an undeniable threat and takes steps to physically guard against the unlawful entry of Mexican workers. It also identifies Mexico as the home of and crossroads for the most undesirable illegal immigrants. ${ }^{78}$ In essence, the "immigration problem" is Mexicans..$^{79}$

Even prior to the change from the INS to the Department of Homeland Security (DHS), "the INS [had] more officers authorized to carry a gun and make arrests than any other federal agency." border to illegal immigration, section 101 of IIRIRA called for an increase in Border Patrol by 5,000 agents, and section 102 authorized the construction of additional physical barriers. To help exercise its deterrence muscle, the Border Patrol also received fixed-wing aircrafts, helicopters,

76. See generally UNDERSTANDING THE I 996 ImMigRation ACt B-2-B-34 (Juan P. Osuna ed., 1997) (annotating and summarizing IIRIRA).

77. See Smith \& Grant, supra note 25, at 89 I.

78. Although IIRIRA never explicitly emphasizes the U.S.-Mexico border, it instructs that Border Patrol agents be deployed and physical barriers be crected in areas of "high illegal entry," including the construction of fencing near San Diego, California. Illegal Immigration Reform and Immigrant Responsibility Act of 1996, Pub. L. No. 104-208, $\S 101,102110$ Stat. 3009-546, 3009-553 to -55 (1996); see, e.g., BILL ONG HING, To BE AN AMERICAN 32-43 (1997) (commenting that, statistically, Mexicans have long been the INS's primary focus and describing the work history of one Mexican client); Kevin R. Johnson, Open Borders?, 51 UCLA L. Rev. 193, 256-58 (2003) (stating that although not the sole group of migrants, Mexican immigrants have been "blamed for promoting social disintegration and exacerbating racial divisiveness by 'refusing' to assimilate").

79. See Edward Funkhouser \& Stephen J. Trejo, Labor Market Outcomes of Female Immigrants in the United States, in The Immigration Debate 239, 271 (James P. Smith \& Barry Edmonston eds., 1998). By all aecounts, Mexiean nationals constitute the largest group of immigrants to the United States each year. While immigration law affects a large variety of peoples, the shared border facilitates legal and illegal migration by Mexicans and Mexican nationals in the U.S. far outnumber those from other countries of origin. See U.S. Census Bureau, Profile of The Foreign-Born Population in THE UNITED STATES: 200012 (2001), available at http://www.census.gov/prod/2002pubs/p23-206.pdf (reporting on the geographic, demographic, social, economic, and housing statistics for the foreign-bom population in the United States). In 2000, the foreign-born population from Mexico accounted for $27.6 \%$ of all foreign-born people in the United States. Id. This proportion is the largest share that one country has contributed to the foreign-born population in the United States since 1890, when Germany contributed about $30 \%$ of the foreign-born population. Id

80. ANDREAS, supra note 22 , at 90 . 
four-wheel drive vehicles, sedans, night-vision goggles, night-vision scopes and sensor units. ${ }^{81}$ In fiscal year 2000, in the Southwest Border Patrol Sector alone, 8,475 agents spent almost 11 million hours on borderenforcement activities. ${ }^{82}$ Still, according to a report by the U.S. General Accounting Office to Congress, "[t] efforts may have affected overall illegal entry along the southwest border remains unclear ...."83 After seven years, insufficient evidence existed to demonstrate the efficacy of the strategy. ${ }^{84}$ According to the U.S. General Accounting Office, Congress's policy analysis arm, the effectiveness of the Southwest Border Strategy codified in the IIRIRA is inconclusive. ${ }^{85}$

After September 11, efforts to secure the southern and northern U.S. borders have been subjected to intensified scrutiny. The border, previously understood mainly as a barrier to the illegal immigration of workers and a safeguard against economic instability, is now also understood as a barrier against the entry of terrorists, who have been added to the earlier list of undesirable immigrants and economic refugees. The border is simultaneously considered a potentially protective seal and a porous threat. The recent political response to increased security concerns along the borders has been to extend the Southwest Border Strategy by advocating for increases in Border Patrol funding and Border Patrol agents.

The perceived value of increased paramilitary (and military) policing along the border increased after September 11 and the perceived threats by outsiders justified the policy choice. Now, as before, fortification of the border presents no consequences for those who live away from it, giving legislators a free hand in pursuing a symbolically powerful, but ultimately ineffective, policy. The border is still a danger zone, but now threats of terrorism trump undocumented immigrants as the publicly identified threat. Now, heightened border security is expected to keep Americans safe from would-be terrorists. The DHS, which in early 2003 combined illegal immigration enforcement functions with legal immigration processing and customs functions, was launched with the stated mission of protecting and defending the American people. ${ }^{86}$ A particular conception of the nation

81. $§ 103$.

82. GAO, SouthWEST Border STRATEGY, supra note 8, at 8 .

83. Id. at 2 .

84. See id. See generally U.S. Gen. Accounting Office, Illegal 1mmigration: Status of SOUTHWEST Border STRATEgy IMPLEMENTATION (1999) (concluding that the data were unavailable to evaluate the effectiveness of the Southwest Border Strategy); U.S. Gen. Accounting Office, Illegal IMmigration: SOUthWest Border Strategy Results Inconclusive; More Evaluation NEEDED (1997) (analyzing the effectiveness of the Southwest Border Strategy and concluding that no results could be reached due to insufficient data).

85. GAO, Southwest Border Strategy, supra note 8, at 2 (concluding that the effect of the Southwest Border Strategy's increases in Border Patrol agents is unclear).

86. See U.S. Dep't of Homeland Sec., Securing Our Homeland: U.S. Department of Homeland Security Strategic Plan 4 (2004), available at http:/www.dhs.gov/dhspublic/ 
grounded in nativistic racism belies this policy discourse: Who is American? Whose rights should be protected?

In keeping with the theme of keeping undesirables out, IIRIRA punishes persons within the United States who have overstayed their visas. Legal immigrants who become illegal due to the expiration of their documents now face harsh penalties that prohibit their return to the United States for either three or ten years. ${ }^{87}$ A previously legal immigrant who overstays her visa by between I80 days and one year is inadmissible for three years. ${ }^{88}$ A previously legal immigrant who is unlawfully present for one year or more is inadmissible for ten years. ${ }^{89}$ IIRIRA imposes a permanent bar to admission for persons ordered removed who later attempt to enter or enter without authorization..$^{90}$ Bars to reentry have encouraged migrant workers and border residents who work in the United States and live in Mexico to stay for longer periods and to send for their family rather than return to their home country. ${ }^{91}$ In attempting to reunite their families, breadwinners living in the United States have become increasingly dependent on the services of smugglers. ${ }^{92}$

The increased penalties burden the border by dramatically increasing the criminal dockets of border courts and filling them with felony immigration cases. Of the eighty-nine federal judicial districts in the fifty states, five are located on the U.S.-Mexico border: California Southern, Arizona, New Mexico, Texas Western, and Texas Southern. These five federal districts account for nearly one-third of all federal criminal suit filings in the country. ${ }^{93}$ From 1997 to 2003 , the overall filings of criminal suits in the

theme_homel.jsp (stating the Department of Homeland Security's "Vision" as "Preserving our freedoms, protecting America ... we secure our homeland." (alteration in original)).

87. 1llegal lmmigration Reform and Immigrant Responsibility Act of 1996, Pub. L. No. 104-208, $\S 301(\mathrm{~b})(1), 110$ Stat. $3009-546,3009-575$ to -78 (1996) (codified as amended at 8 U.S.C. $\S$ $1182(\mathrm{a})(9)(\mathrm{B})(\mathrm{i})(1)(2000))$.

88. Id.

89. 8 U.S.C. $\S 1182(a)(9)(B)(i)(I 1)(2000)$.

90. $\S 1182(\mathrm{a})(9)(\mathrm{C})(\mathrm{i})(1)$.

91. A Houston Chronicle article explains this phenomenon:

[T] he growth in child smuggling paradoxically reflects how difficult it is to get into the country these days. With the border now better patrolled, immigrants no longer have an easy time going home to spend the winter with their families. So they are willing to spend small fortunes for smugglers to get their kids across ....

Edward Hegstrom, A Risky Border Business, Houston Chron., Aug. 19, 2002, at A1.

92. Id.

93. This information is based on Federal Court Management Statistics reports for District Courts in 2003, which are located on the U.S. Courts' website. Admin. OfFice of THE U.S. Courts, U.S. District Court - Judicial Caseload Profile Report (2003), available at http://www.uscourts.gov/ cgi-bin/cmsd2003.pl (last visited Oct. 4, 2004) [hereinafter Judicial CaSeload Profile Report 2003] (reports for the following federal judicial districts are on file with the California Law Review: All District Courts, California Southern, Arizona, New Mexico, Texas Western, and Texas Southern). These figures exclude judicial districts in U.S. territories. In 2003, all federal districts combined reported 58,294 criminal felony filings. $I d$. The five border districts combined reported 18,726 criminal felony filings. $I d$. Of the 89 districts, the five border districts rank first through fifth in highest criminal 
five border federal district courts increased by $104 \% .{ }^{94}$ In the other eightyfour districts, criminal filings increased by $41 \%{ }^{95}$ Immigration filings explain a significant proportion of these increases." "Since 1997, immigration case filings have increased $166 \%$ (up 1,074 cases) in the District of Arizona, I63\% (up 402 cases) in the District of New Mexico, $157 \%$ (up 1,178 cases) in the Southern District of Texas, and $57 \%$ (up 480 cases) in the Western District of Texas, whereas filings decreased $20 \%$ (down 384 cases) in the Southern District of California." 97 In some jurisdictions, the increases result in higher caseloads for judges in the district, and in others, the increases have required visiting judges to fill the gaps in judicial availability. ${ }^{98}$

Furthermore, increased measures of border control and stiff bars to reentry burden a large proportion of border peoples, including undocumented immigrants in the United States, both those who originally entered through legal channels and those who entered without authorization. ${ }^{99}$ Criminalizing persons already in the country and punishing them with long-term bans illustrates the extent to which immigrants are viewed as unwanted invaders. By association, Mexican-appearing persons become suspected illegal immigrants who bear the weight of the policy's message: leave immediately and never come back. If policymakers predicted these disproportionate effects on border peoples, they chose other priorities and failed to adequately compensate for the adverse effects. The reigning

felony cases commenced: Texas Southern (1); Texas Western (2); California Southern (3); Arizona (4); New Mexico (5). See Leonidas Ralph Mecham, Admin. Office of the U.S. Courts, Judicial Business of the United States Courts, 2003 Annual Report of the Director, tbl. D-1 (2002), available at http://www.uscourts.gov/judbus2003/appendices/d1.pdf.

94. In 1997, the border districts reported a combined total of 9,158 criminal felony filings. Admin. Office of the U.S. Courts, U.S. District Court-Judicial Caseload Profile Report (1997), available at http://www.uscourts.gov/cgi-bin/cms.pl (last visited Oct. 4, 2004) [hereinafter Judicial Caseload Profile Report 1997] (reports for the following federal judicial districts are on file with the California Law Review: All District Courts, California Southern, Arizona, New Mexico, Texas Western, Texas Southern). In 2003, the border districts reported a combined total of 18,726 criminal felony filings. Judicial CASEload Profile RePort 2003, supra note 93.

95. In 1997, the eighty-four nonborder districts reported 28,673 total criminal felony filings; in 2003, they reported 38,111 criminal felony filings. Judicial Caseload Profile Report 1997, supra note 94; Judicial CASEload Profile Report 2003, supra note 93.

96. Immigration filings rose for nine consecutive years, growing over $430 \%$ between 1992 and 2000. Admin. Office of the U.S. Courts, Federal Judicial Caseload: Recent Trends 9 (2001), available at http://www.uscourts.gov/recenttrends2001/20015yr.pdf (last visited July 3, 2004). They declined $10 \%$ in 2001 to 11,045 . Id.

97. Id.

98. In New Mexico, a string of federal court judges took turns visiting Las Cruces because the city had no full-time federal judge. Las Cruces Federal Court Carries on Without Judge, EL Paso Times, June 17, 2003, at 7B ("The federal court in Las Cruces-facing a rising caseload because of a crackdown on drug smuggling and illegal immigration-has no full-time federal judge."). One federal judge now sits in Las Cruces, New Mexico; Hon. Robert C. Brack received a commission on July 15 , 2003.

99. See Helfand, supra note 5, at 90 (commenting that most undocumented immigrants are those who overstayed visas). 
pattern of national policy priorities reveals a national identity infused with nativistic racism. This concept of nation maintains subjugation of border peoples and prevents consideration of border peoples as full participants in American society. It manifests as philosophically contradictory trade and immigration policies that create the conditions for the mistreatment of border peoples and the encroachment on the rights of border peoples.

\section{Immigrant Smuggling}

While NAFTA aims to "eliminate barriers to trade in, and facilitate the cross-border movement of, goods and services between the territories of the Parties," 100 the INS's Southwest Border Strategy aims to "close off the routes most frequently used by smugglers and illegal aliens (generally through urban areas)." 101 Both trade and immigration policies address the cross-border movement of people, and the same channels facilitate migration for both purposes; the routes most frequently traveled by smugglers are also used for NAFTA exchanges. ${ }^{102}$ Yet, as NAFTA opens the border, IIRIRA closes it. As predicted by then-President Clinton in 1994, "efforts to facilitate travel across the U.S.-Mexico border as part of the North American Free Trade Agreement may conflict with the need to establish closer controls on cross-border traffic to enforce immigration laws." 103

To deter fraudulent entries, IIRIRA stiffened civil and criminal penalties for document fraud and false claims to citizenship. ${ }^{104}$ The legislation increased the penalty for fraud and misuse of government-issued identification documents increased from five to fifteen years imprisonment. ${ }^{105}$ The IIRIRA changed the law such that people found guilty of other document fraud crimes may be imprisoned for ten years for their first or second offense. ${ }^{106}$ Liability extends to those who prepared, filed, or assisted with false document production to obtain a benefit. ${ }^{107} \mathrm{~A}$ person convicted twice of such assistance faces up to fifteen years in jail. ${ }^{108}$ Not surprisingly, fraudulent documents and false claims to citizenship occur most often at legal border crossing points. Illegal workers who face a daily fear of

100. NAFTA, supra note 7, at art. 102.

101. GAO, SOUTHWEST Border Strategy, supra note 8 , at 4.

102. See ANDREAS, supra note 22, at 20 ("[A]lthough the methods are as diverse as the commodities, most smuggling parallels the methods and routes of legal commerce.").

103. Id. at 103 (quoting ACCepting the Immigration Challenge: The President's Report on IMMIGRATION 42 (1994))

104. Illegal Immigration Reform and Immigrant Responsibility Act of 1996, Pub. L. No. 104-208, $\S \S 211-215,110$ Stat. 3009-546, 3009-569 to -72 (1996) (codified as amended in scattered sections of 8

U.S.C. and 18 U.S.C.).

105. $\$ 211(\mathrm{a})(1)(\mathrm{A})$ (codified as amended at 18 U.S.C $\S 1028(\mathrm{~b})(1)(2000)$ ).

106. $\$ 211(\mathrm{a})(2)$ (codified as amended at 18 U.S.C. $\S \S 1425-1427,1544-46(a)(2000)$ ).

107. $\S 213$ (codified as amended at 8 U.S.C. $\S 1324 \mathrm{c}(2000)$ ).

108. Id. 
apprehension bear these risks of punishment as the transaction costs necessary to yield the benefit of a U.S. paycheck.

In measuring the effectiveness of its efforts to deter illegal immigration, INS analyses used number of apprehensions as the measure of success, such that high apprehension figures "demonstrate the U.S. capacity for interdiction and deterrence." 109 Border policing initiatives in the mid1990s-Operation Hold-the-Line and its progeny-yielded steep increases in the numbers of illegal migrants apprehended at the border. ${ }^{110}$ But using apprehensions as a measure of success ignores the smuggling market created by the enforcement initiatives and the increased dependence of unauthorized migrants on professional smugglers. ${ }^{11}$ The increased interdictions might indicate a failure to deter migration, rather than an effective blockade.

IIRIRA tightened border controls ${ }^{112}$ and increased criminal penalties for persons illegally entering the United States, making false claims to citizenship, ${ }^{113}$ and using fraud to procure documents ${ }^{1 / 4}$ have contributed to the proliferation of immigrant smuggling. ${ }^{115}$ These penalties raise the stakes (and profits) for coyotes, whose clandestine activities often follow the legal channeIs of trade made possible by NAFTA. ${ }^{116}$ The parallel markets verify the connection: $75 \%$ of U.S.-Mexico trade passes through Texas, ${ }^{117}$ and the INS strategy to combat smuggling prioritized the South/Central Texas corridor as its first focus. ${ }^{118}$

109. Peter H. Smith, NAFTA and Mexican Migration, in At the Crossroads: Mexico and U.S. ImMigration Policy 267, 276 (Frank D. Bean et al. eds., 1997).

I10. See Martin, supra note 14, at 13 I.

111. See Spener, supra note 20; U.S. Gen. Accounting Office, Alien Smuggling: Management and Operational Improvements Needed to Address Growing Problem 7 (2000) ("INS' November 1999 INS Intelligence Assessment stated that illegal border-crossers have increasingly relied on alien smugglers to enhance their chances of successfully entering the United States." (footnote omitted)).

112. $\S 101$ (codified as amended in scattered sections of the U.S.C.) (increasing border patrol agents and support personnel); $\S 102$ (codified as amended at 8 U.S.C. $\S 1103(2000)$ ) (improving barriers at border).

113. $\S 215$ (codified as amended at 18 U.S.C. $\$ 1015$ (a) (2000)) (increasing criminal penalties for false claim to citizenship).

114. $\S 211$ (codified as amended at 18 U.S.C. $\S 1028$ (b) (2000)) (increasing criminal penalties for fraudulent use of government-issued documents); $\S 212$ (codified as amended at 8 U.S.C. $1324 \mathrm{c}$ (2000)) (creating new document fraud offenses and new civil penalties for document fraud); $\$ 214$ (codified as amended at 18 U.S.C. $\S 1546(a)(2000)$ ) (adding criminal penalties for knowingly presenting document which fails to contain reasonable basis in law or fact).

115. Some scholars argue that smuggling takes place when there is a gap between a state's authority to create laws and its power or willingness to enforce them. See ANDREAs, supra note 22, at 22 ("[S]muggling is defined by and depends on the state's exercising its metapolitical authority to criminalize without the full capacity or willingness to enforce its laws."); see also Immigrant Smuggling Is on Rise, Agents Say, L.A. TIMEs, May 27, 2003, at B5.

116. See ANDREAS, supra note 22, at 97; Spener, supra note 20, at 130.

117. Spener, supra note 20, at 129.

118. See U.S. Gen. Accounting Office, supra note 111, at 12. (outlining the INS's antismuggling strategy). 
Coyotes sometimes provide fraudulent documents or attempt to cross 100 or more migrants at a time in semi-trucks. ${ }^{119}$ They have developed sophisticated methods for transporting migrants, including "in eighteen-wheelers that blend in with the boom in cross-border trucking brought on by the liberalization of trade." 120 The risk often pays off, as border inspectors cannot possibly search every (supposed) NAFTA truck without paralyzing the bridges and backing up the border. ${ }^{121}$ Profits in the smuggling enterprise rise with additional danger, including the risk of harsh IIRIRA-mandated penalties for smugglers themselves. ${ }^{122}$

The use of semi-trucks for smuggling immigrants has ended in tragedy for many unauthorized immigrants. In July 2002, two Mexicans died of heatstroke during a 600-mile trip from El Paso to Dallas in an unventilated tractor-trailer filled with forty undocumented immigrants. ${ }^{123}$ Four days later, just outside of San Antonio, police found a group of thirty-two undocumented immigrants yelling for their lives from the back of an eighteen-wheeler. ${ }^{124}$ The next month, Border Patrol agents discovered fiftyone undocumented immigrants locked in a trailer during a checkpoint inspection in Laredo. ${ }^{125}$ With NAFTA facilitating the swift movement of goods and IIRIRA militarizing the border, smuggling operations have increasingly used trucks as the transport mechanism of choice.

The smuggling trade has also become increasingly violent. Coyotes use kidnapping, extortion, and murder to exact additional fees from unauthorized immigrants. Immigrants illegally in the United States are unlikely to leave due to the severe bars on admissibility, so many attempt to have their families join them in the United States rather than return. Some coyotes kidnap persons crossing the desert and demand money from them or their family members to secure their release. ${ }^{126}$ Some who are unable to

119. See ANDREAS, supra note 22, at 97; Spener, supra note 20, at 127.

120. ANDREAS, supra note 22, at 97.

121. Id.

122. Illegal Immigration Reform and Immigrant Responsibility Aet of 1996, Pub. L. No. 104-208, $\S 203,110$ Stat. $3009-546,3009-565$ to -66 (1996) (codified as amended at 18 U.S.C. $\S 1324$ (2000)) (enhancing enforcement efforts and penalties against smuggling of immigrants).

123. Dick Stanley, Police Find More Migrants in Stifling Tractor-Trailer, Austin AM.Statesman, Aug. 1, 2002, at B5. According to the indictment, between 1999 and 2002, the smuggling organization responsible for this incident organized from one to five trips per week, each of which transported between five and 100 undocumented immigrants. Id.

124. Id.

125. Press Release, U.S. Department of Justice, Immigration and Naturalization Service, Border Patrol Rescues 51 Migrants in Laredo: Salvadoran, Honduran and Mexican Nationals Sealed in Tractor-Trailer (Oct. 23, 2002) (on file with California Law Review).

126. Jacques Billeaud, Immigrant Kidnappings on the Rise as Border Smuggling Turns More Lucrative and Violent, SAN DiEgo Union-TRIB., Jan. 24, 2003, http:/www.signonsandiego.com/news/ mexico/20030123-1101-kidnappingimmigrants.html; Hegstrom, supra note 91; see also Harvey Rice, Man's Time Served in Extortion, Houston ChroN., July 20, 2004, at B3 (reporting that an alleged smuggler held an immigrant's three-year-old son for ransom). 
pay the ransom have been killed. ${ }^{127}$ Abuse by coyotes has become more prevalent as well, as those with information about abuses are unlikely to report them due to the possibility of deportation for themselves or the persons subject to abuse.

Furthermore, additional smugglers have entered the market as the profit potential rises. ${ }^{128}$ In the fall of 1995 , smuggling prices increased from $\$ 200-300$ per person to $\$ 300-400 .{ }^{129}$ By mid-1999, Mexican nationals paid up to $\$ 1,000$ to be smuggled into the United States. ${ }^{130}$ After September 11, costs have grown to more than $\$ 1,500$ per person. ${ }^{131}$ Despite the increased cost, the U.S. strategy of deterrence forces immigrants to enter the smuggling game. ${ }^{132}$

While one might expect higher smuggling costs to deter immigrants from employing coyotes, some of the costs have been taken up by employers seeking to hire illegal workers. In December 2001, Tyson Foods was indicted in the largest immigrant smuggling case against a U.S. corporation. ${ }^{133}$ The company denies knowledge of the operation, but evidence indicates that Tyson's managers requested 2,000 Mexican and Central American workers and paid smugglers $\$ 100-\$ 200$ per worker to deliver them. ${ }^{134}$ Despite testimony by an undercover Border Patrol agent posing as a smuggler who described delivering 136 immigrants to Tyson plants, the jury acquitted those Tyson managers who did not make plea agreements. ${ }^{135}$

This instance of employer-based immigration enforcement greatly contrasts with the usual patterns for immigration enforcement employed by the INS. ${ }^{136}$ The INS only apportioned about $2 \%$ of its budget to enforcing employer sanctions that would target the demand side of the illegal

127. Id.

128. See ANDREAS, supra note 22, at $97-98$ (describing the shift from small smuggling groups to more sophisticated smuggling operations).

129. See Martin, supra note 14, at 131.

130. Spener, supra note 20, at 127; REYES ET AL., supra note 42, at 61 ("[C]rossing from Tijuana to Los Angeles in 2000 cost about $\$ 800$, but the price rose to $\$ 2,000$ if the crossing involved passing through a checkpoint.").

131. Steven Kreytak, Mexican Immigrant Smugglers Sentenced, Austin Am.-STatesman, Jan. 29,2004 , at B1 (stating that immigrants agreed to pay $\$ 1,500$ to $\$ 1,800$ each for passage into the United States).

132. See ANDREAS, supra note 22 , at 95 (reporting on surveys finding that nearly $75 \%$ of illcgal Mexican immigrants usc the services of a smuggler).

133. Kevin Sack, Under the Counter, Grocer Provided Workers, N.Y. TIMES, Jan. 14, 2002, at A13.

134. See id.; Jury Acquits Tyson Foods in Immigrant Conspiracy Case, CNN.com, Mar. 26, 2003, at http://www.cnn.com/2003/LAW/03/26/tysons. food.ap/index.html.

135. Id. Of the six defendants named in the thirty-six count indictment, two made plca agrecments, one fatally shot himself prior to the trial, and three were acquitted. Id.; see also United States v. Tyson Foods, 258 F. Supp. 2d 809 (E.D. Tenn. 2003) (describing charges that survived dismissal).

136. See Jenny Schulz, Note, Grappling with a Meaty Issue: IIRIRA's Effect on Immigrants in the Meatpacking Industry, 2 J. GENDER RACE \& JUST. 137 (1998) (noting that IIRIRA fails to penalize employers for illegally hiring undocumented workers). 
immigration equation. ${ }^{137}$ Such sanctions have been neglected as a potential alternative to increased border militarization. As part of immigration reforms enacted in 1986, Congress introduced employer sanctions to discourage employers from hiring illegal workers. ${ }^{138}$ Employers, though not responsible for verifying the authenticity of documents presented by employees, could be fined up to $\$ 2,000$ per immigrant for their first violation of employing an undocumented worker. ${ }^{139}$ Deficiencies in enforcement meant that the 1986 reforms were never truly tested: in 2002, the INS issued only fifty-three Notices of Intent to Fine employers. ${ }^{140}$ Employer sanctions under the Immigration Reform and Control Act (IRCA) proved difficult to impose because the INS must show that employers knowingly hired illegal immigrant labor. ${ }^{141}$ This intent requirement is difficult to overcome. While employer sanctions may not offer the best alternative to border fortification, a shift toward such internal measures and away from the border perhaps would alleviate some of the harms to border peoples. Such a shift, however, does little to retrain the national concept away from nativistic-racism based ideals.

In the ongoing immigration policy debate, border enforcement prevails as the preferred method of so-called deterrence and protection. As controls on immigration have tightened and border fortification has intensified, immigrant smuggling has increased in sophistication and profitability. As the channels have opened for free trade, immigrant smugglers have begun to utilize a convenient method for transporting persons seeking entry into the United States. Juxtaposing free trade and border fortification with the current state of employment-based immigration enforcement, it is evident that the proliferation of immigrant smuggIing has been cultivated by U.S. policy. If this brutal, profitable, and deadly trade is an appropriate and calculated tradeoff of overall domestic economic growth, then the calculus itself must be saturated with nativistic racism.

137. ANDREAS, supra note 22, at 100-01.

138. Immigration Reform and Control Act of 1986, Pub. L. 99-603, 100 Stat. 3359 (1996) (codified as amended at 8 U.S.C.).

139. Id.

140. U.S. Dep't of Homeland Sec., Yearbook of Immigration Statistics, 2002186 (2003), available at $\mathrm{http} / /$ uscis.gov/graphics/shared/aboutus/statistics/yearbook2002.pdf. In years prior to 1996, the INS routinely issued more than 1,000 Notices of Intent to Fine to employers per year. U.S. Immigration and Naturalization Serv., Statistical Yearbook of the Immigration and NATURALIZATION SERVICE, I997 175 (1999), available at http://uscis.gov/graphics/shared/aboutus/ statistics/1997YB.pdf (covering fiscal years 1991-97); see also JoAnne D. Spotts, U.S. Immigration Policy on the Southwest Border from Reagan Through Clinton, 1981-200I, I6 Geo. IMmigr. L.J. 601, 610-12 (2002).

141. $\S 101$ (codified as amended at 8 U.S.C. $\S 1324 \mathrm{a}(2000)$ ) (employers establish an affirmative defense to a charge of knowingly employing an undocumented immigrant by showing that they complied with all identity validation requirements in good faith). 


\section{Vigilante Justice}

The U.S. border-enforcement strategy, which has concentrated on urban crossings, has succeeded both in motivating sophisticated clandestine immigrant smuggling operation s $^{142}$ and pushing immigrant crossers to nonurban areas. ${ }^{143}$ Nonurban apprehensions along the border have increased since $1996 .^{144}$ From fiscal year 1997 to fiscal year 1999, the number of immigrants apprehended by the INS increased by nearly $80 \% .{ }^{145}$ The level of border-enforcement activity at the major border entry points now redirects illegal crossers to more treacherous rural areas. ${ }^{146}$ This borderenforcement strategy has set the stage in rural areas for a surge of vigilante justice.

In rural areas, most notably in Texas and Arizona, some ranchers now take Border Patrol business into their own hands. Tales of vigilante justice by landowners amount to more than local legend. When immigrants traverse some landowners' property en route to their new homes, they may face armed militias ready to defend their property and their country. ${ }^{147}$ "During the past two years, Mexicans passing through this corner of South Texas [from Del Rio to El lndio] have been the targets of six shootings. Two of the victims were killed. All of them were shot in the back." "48 After a South Texas rancher admitted to killing an undocumented Mexican immigrant on his property, he was fined $\$ 4,000$ and sentenced to 180 days of probation. ${ }^{149}$ In Arizona, anti-immigrant vigilantes organize their own strategies to combat the "invasion' of migrants from south of the border." 150 Ads recruiting volunteers for a "neighborhood ranch watch" ask vacationers to help protect the ranchers' property from unlawful trespass. ${ }^{151}$ The public advertisements and the light penalties for some of these

142. See ANDREAS, supra note 22, at 23.

143. GAO, SOUTHWest Border Strategy, supra note 8 , at $4,10$.

144. See id. at 2.

145. U.S. Gen. ACCOUNTING OfFICE, supra note 111 , at 12.

146. See GAO, Southwest Border STRATEgy, supra note 8, at 3. See generally Colloff, supra note 42, at 98-103, 162-69 (describing a "war zone" in rural Texas where illegal immigrants enter the United States and some ranchers have turned to vigilante justice).

147. See Colloff, supra note 42, at 98-103, 162-69; Pauline Arrillaga, Border War, Portsmouth Herald, Aug. 20, 2003, http://www.seacoastonline.com/2000news/8_20_w1.htm; John W. Gonzalez, Rancher Convicted in Immigrant's Death, Houston Chron., Aug. 25, 2001, at 33A; John MacCormack, Open Season, Dallas ObServer, May 30, 2002, at 33-37.

148. Colloff, supra note 42, at 99; see also Jack McGarvey, Border Vigilantes Attract the Wrong Crowd, Denver Post, June 18, 2000, at 1G.

149. MacCormack, supra note 147. Sam Blackwood was charged with and convicted of misdemeanor deadly conduct. No evidence of self-defense was presented for the murder of Eusebio de Haro, who had asked Blackwood for a glass of water, then turned away when it was refused. "Blackwood then shot him in the back of the leg and stood by smoking a pipe while de Haro bled to death." For a full description of the facts, see the Texas Court of Appeal opinion, Blackwood v. State, No. 04-01-0833-CR, 2002 WL 31253536, at *1 (Tex. App. 2002).

150. McGarvey, supra note 148.

151. See, e.g., Ranch Rescue, at http://www.ranchrescue.com (last visited Oct. 4, 2004). 
vigilante killings indicate a phenomenon that stretches beyond the realm of unconscious nativistic racism. ${ }^{152}$ Furthermore, more instances of vigilante justice may go unreported; the difficulty in detecting crimes against illegal migrants that take place in remote areas likely indicates that the number of crimes reported may not accurately reflect the activity. ${ }^{153}$

Vigilante justice shows the extent to which the nativistic racist perspective extends beyond policymakers to law-abiding citizens. However, silence on the part of judicial and policymaking bodies in response to vigilante justice indicates assent. The failure of U.S. authorities to meaningfully work against these instances of brutality reinforces the national vision of who matters and who is expendable. ${ }^{154}$ In this way, the dehumanization of Mexicans implicitly supported by the U.S. government affects all border peoples. Moreover, if Border Patrol agents may include Mexican appearance as part of their reasonable suspicion checklist, and they often wrongly stop citizens and legal permanent residents, what is the consequence of a similar false positive by a gun-toting immigrant-hunter? ${ }^{155}$

\section{Abuse by Border Patrol}

The Southwest Border Strategy calls for the improvement of physical barriers at the border to deter illegal immigration. ${ }^{156}$ IIRIRA provides that hiring and training standards be "consistent with relevant standards of professionalism," 157 but it fails to address the Border Patrol's checkered history of abuse in the Southwest. ${ }^{158}$ Thus, although IIRIRA's text deals with

152. MacCormack, supra note 147 (describing the deaths of Luis Armando Chavez Vaquera, age 16, in Vega Verde, Texas; Abecncgo Monje Ortiz, age 18, north of Eagle Pass, Texas; and Eusebio de Haro, age 22, in Bracketvillc, Texas); see also Blackwood, 2002 WL 31253536; MIKE DAvIS, MAGICAL URBANISM 39-47 (2000).

153. See GAO, Southwest Border Strategy, supra note 8, at 19.

154. As noted by the district attorney who prosecuted these vigilante justice cases in Val Verde County, "[T]hese men [who pursue immigrants] . . have one thing in common. They are all white men who come a long way from Texas." MacCormack, supra note 147, at 37.

155. In 2000, 12,757 citizens and legal permanent residents were processed by the Border Patrol. U.S. Immigration and Naturalization SERv., Sta tistical Yearbook of the Immigration and NATURALIZATION SERVICE, 2000243 (2002), available at http://uscis.gov/graphics/shared/aboutus/ statistics/Yearbook2000.pdf. Deportation processing represents the most extreme form of a false positive-when the Border Patrol wrongly believes someone to be in the country illegally. These numbers do not include the number of persons stopped and questioned by Border Patrol under "reasonable suspicion" of illegal status.

156. Illegal Immigration Reform and Immigrant Responsibility Act of 1996, Pub. L. No. 104-208, $\S 102,110$ Stat. $3009-546,3009-554$ (1996) (codified as amended at 8 U.S.C. $\S 1103(2000)$ ) (introducing additional physical barriers to the border).

157. $\$ 106$ (ordering review of INS hiring and training standards).

158. In addition, racial profiling frequently escapes review due to its legality in the immigration context. See, e.g., Murillo v. Musegades, 809 F. Supp. 487, $491-95$ (W.D. Tex. 1992) (listing representative instances in which Hispanic U.S. citizens were harassed by Border Patrol agents). See generally AlFREdo MiRANDE, GRINGo JUSTICE 100-45 (1987) (documenting the history of southwest border policing); Kevin R. Johnson, The Case Against Race Profiling in Immigration Enforcement, 78 WASH. U. L.Q. 675 (2000) (arguing against the use of racial profiling in immigration control). 
a strategy of border militarization for deterring illegal immigration, it neglects the strategy's consequences of increased Border Patrol and surveillance on border residents, such as citizens, legal residents, and undocumented immigrants.

In 1992, a federal district court enjoined Border Patrol conduct that constituted a pattern and practice of interrogating and intimidating, sometimes at gunpoint, Mexican Americans on and around a high school campus located yards from the border. ${ }^{159}$ In this El Paso, Texas, neighborhood, high school students, faculty, and staff were routinely asked to verify their citizenship. Border Patrol vehicles were seen tearing across the football field in pursuit of suspected illegal immigrants. ${ }^{160}$ Walking home from school, students were stopped, questioned, "insulted, humiliated, degraded, and embarrassed." 161 The suit resulted in an injunction, and the settlement agreement required Border Patrol training and education, the institution of a bilingual complaint hotline, and the initiation of new complaint procedures. ${ }^{162}$ Two years after the injunction, Operation Hold-the-Line debuted, effectively shutting the border by deploying large numbers of Border Patrol agents to the front line.

In 1997, a report produced by the Arizona, California, New Mexico, and Texas Advisory Committees to the U.S. Commission on Civil Rights documented the history of civil rights violations, from unlawful stops to deaths at the hands of Border Patrol agents and border-patrolling military ${ }^{163}$ to the effects of border militarization on border communities. ${ }^{164}$ The report found that "[b]order communities in the Southwest are uniquely impacted by the presence of large-scale Federal immigration law enforcement activity ... [ [and] such policing oftentimes serves to diminish the protection of civil rights, especially for Hispanics." 165 Still, strict immigration reforms and control of the southern border remain significant components of

159. See Murillo, 809 F. Supp. at 487 (issuing an injunction against the Border Patrol in a class action suit by border residents).

160. Id. at 495

161. Id.

162. Murillo v. Musegades, No. EP-92-CA-319(B) (W.D. Tex. Feb. 23, 1994) (final order) (on file with the California Law Review).

163. See, e.g., Spener, supra note 20 , at 129 (describing the shooting of a Tcxas goat herder by a Marine enlisted to patrol the border); ARizona, California, New MeXico, and TeXas Advisory Committees to the United States Commission on Civil Rights, Federal immigration Law Enforcement in the Southwest: Civil Rights Impacts on Border Communities 12-51 (I997) [hereinafter Advisory Committees Report]; Debbie Nathan, Rodney King South: The Feds Turn the Border into a Killing Field, L.A. WeEkLY, Jan. 8, 1993, at 10 (covering a shooting by a Border Patrol agent of a Mexican man on the Arizona bordcr).

164. ADVISORY COMMITTEES REPORT, supra note 163, at 12-51. See generally Helfand, supra note 5, at 93-100 (arguing that the public has been desensitized to border violence and describing incidences of physical abuse); Jesus A. Trevino, Comment, Border Violence Against Illegal Immigrants and the Need to Change the Border Patrol's Current Complaint Review Process, 21 Hous. J. INT'L L. 85 (1998) (describing violence by Border Patrol).

165. AdVISORY CoMmittees Report, supra note 163, at 6. 
policies meant to suit the national interest. The national interest again excludes border peoples; policies that suit the national interest draw from and feed nativistic racism and the devaluation and dehumanization of border peoples.

The drive to secure the country's borders is grounded in nativistic racism and has recently manifested as the need to protect the country from terrorism. ${ }^{166}$ The September 11 attacks sparked a heightened sense of vulnerability and a strengthened sense of U.S. nationalism. Foreigners suddenly became understood as imminent threats to American safety. Arab- and Muslim-looking people, regardless of legal status, citizenship, profession, allegiance, or criminal history, immediately were deemed extranational. ${ }^{167}$ Consistent with the intense need to insulate the United States, the government flagged the border as a site for additional military presence and advanced surveillance and intelligence techniques. ${ }^{168}$ Nativistic racism in the United States was reinvigorated as Arab and Muslim Americans became the immediate targets of the anti-immigrant sentiment that surged throughout the country.

While harsh post-September 11 security and immigration measures do not overtly target border peoples, they again leave border peoples outside the realm of national consideration. ${ }^{169}$ Fortifying the U.S-Mexico border with additional Border Patrol agents may reassure Americans that any holes in national security have been patched, but the effectiveness of the strategy remains unproven. However, effectively transforming the border into a militarized zone certainly and negatively affects border peoples. The job directives of Border Patrol agents may have expanded to include terrorists, but their main mission of interdicting illegal immigrants remains in force. In this vein, border peoples' right to be in the United States will be disputed daily and the everyday harms of border militarization will persist. ${ }^{170}$ The border-based threat has in some ways shifted from joblessness to terrorism, but the result remains the same for border peoples. Alongside

166. See Doris Meissner, Carnegie Endowment for 1nT'l Peace, After the AtTacks: Protecting Borders ANd Liberties 1 (2001) ("The September 11 terrorist attacks abruptly shifted the U.S. immigration debate from liberalizing policy with Mexico to deep misgivings about border controls.").

167. See generally Muzaffar A. Chishti et al, Migration Policy Inst. Report, America's Challenge: Domestic Security, Civil liberties, and National Unity After September i I (2003) (examining immigration in the context of national security and suggesting the ineffectiveness of the use of immigration controls as anti-terrorism measures).

168. Office of Mgmt. \& Budget, Fiscal Year 2003 Budget of the U.S. Government 4 (2002), available at http:/www.gpoaccess.gov/usbudget/fy03/pdf/budget.pdf. The president's budget proposal describes "securing our borders" as one of four "urgent and essential missions." Id. at 17. The budget proposal called for $\$ 21$ billion for the achievement of its four missions. Id.

169. See generally Kevin R. Johnson, September $l l$ and Mexican Immigrants: Collateral Damages Comes Home, 52 DePaul L. REv. 849 (2003) (tracing changes in immigration law and policy after September 11 and applying them to Mexican immigrant communities).

170. See infra Part IV.A. 
the day-to-day harms of border militarization, the livelihood of many border peoples has been compromised. The message of the policy choices is consistent: when setting policies to protect the national interest, the welfare of border peoples is secondary.

\section{B. Lost Jobs and Unprotected Labor}

NAFTA was often seen as "a trade-off between expanded imports of Mexican goods and expanded 'imports' of Mexican people, legal and illegal." 171 Its drafters justified their approach not by considering the peoples immediately affected, but by emphasizing that the agreement would prove economically beneficial for all three member countries and that the resulting economic growth in Mexico would serve as a natural deterrent to labor migration. ${ }^{172}$ Workers and labor unions, however, made two different predictions: jobs would be exported to Mexico, and NAFTA would create the potential for hazardous working conditions and increased discrimination. ${ }^{173}$ Responding to concerns over lost jobs and anticipating the displacement of workers due to the movement of factories to Mexico, Congress authorized special worker (re)training programs for those displaced in NAFTA-related closures. ${ }^{174}$ To quell critics' concerns over working conditions and discrimination, the North American Agreement on Labor Cooperation (NAALC) was introduced as a supplement to NAFTA. ${ }^{175}$ U.S. workers were assured that any jobs lost would be far outweighed by those created and that labor standards in all three member countries would be enforced.

Since NAFTA entered into force, the Department of Labor has certified more than half a million workers as displaced by NAFTA-related trade and shifts in production location. ${ }^{176}$ The NAFTA-Transitional Adjustment Assistance Program assisted workers who lost their jobs because their company directly or indirectly was affected by trade with Canada and

171. Daniel Trefler, Immigrants and Natives in General Equilibrium Trade Models, in THE Immigration DeBate 206 (James P. Smith \& Barry Edmonston eds., 1998).

172. Id.; Philip L. Martin, Economic Integration and Migration: The Case of NAFTA, 3 UCLA J. INT'L L. \& FOREIGN AFF. 419, 422 (1998-99).

173. Sarah Lowe, Comment, The First American Case Under the North American Free Trade Agreement on Labor Cooperation, 51 U. MiAmI L. Rev. 481, 487-88 (1997); Kate E. Andrias, Gender, Work, and the NAFTA Labor Side Agreement, 37 U.S.F. L. REv. 521, 532-33 (2003).

174. North American Free Trade Implementation Act, Pub. L. No. 103-182, §§ 501-544; 107 Stat. 2057, $2149-70$ (1993) (codified as amended in scattered sections of 19 U.S.C.).

175. North American Agreement on Labor Cooperation, Sept. 13, 1993, U.S.-Mex.-Can., art. 1, 32 1.L.M. 1499 [hereinafter NAALC]. Like NAFTA, the NAALC failed to address the historical mobility of labor between Mexico and the United States. See Johnson, supra note 13, at 954; Nelson, supra note 14 , at 987 .

176. Public Citizen, NAFTA-Transitional Adjustment Assistance 1994-2002, at http://www.citizen.org/trade/forms/taa_search.cfm?dataset=1 (describing the program that concluded at the end of 2002 with an estimated 525,094 worker certifications) (last visited Sept. 22, 2004). 
Mexico. ${ }^{177}$ While NAFTA-related job losses have hit states throughout the country, Texas and California both place within the top five states with the most job losses. ${ }^{178}$

The adequacy of training for border peoples also bears mention. Displaced workers in El Paso, Texas, filed a suit challenging the sufficiency of the federal job-training program. ${ }^{179}$ Workers cite the availability of training programs conducted either in Spanish or bilingually as inadequate for their needs. Given the short period of time for training-eighteen months-and the low levels of education among NAFTA-displaced workers, displaced workers may enter a GED or English as a Second Language program and never progress to vocational training. ${ }^{180}$ If economic justifications alone drove policy choices, then one would infer that trained workers are preferable to untrained workers.

Predictably, free trade's reverberations were felt in Texas and California in the form of lost jobs. Also predictably, the training needs of NAFTA-displaced workers in border communities (and other communities with high populations of Spanish speakers) demanded more than Congress provided. The ideology of nativistic racism again surfaces, as training programs supposedly designed to help displaced workers do not respond to the needs of border peoples. Training that may be sufficient for fluent English speakers is truncated for many border peoples. Deficiencies in technical training offset any employment gains due to increased English capabilities.

As the first agreement to lift trade barriers between a developing nation and a bordering developed nation, NAFTA purported to correct the "immigration problem" "181 by creating jobs in Mexico and thereby removing incentives for Mexican migration. ${ }^{182}$ However, in addition to displacing U.S. industrial workers, NAFTA displaced Mexican agricultural workers. Mexican farmers from states generally resistant to emigration faced serious competition due to the reduction and elimination of tariffs on U.S. food products. ${ }^{183}$ Facing the next step in removing tariffs on farm goods, Mexican farmers protested NAFTA and pleaded with the Mexican government to renegotiate the farm-related portions of NAFTA. ${ }^{184}$ Farmers

177. U.S. Gen. Accounting Office, Trade adjustment assistance: Experjences of Six TRADE-IMPACTED COMMUNITIES 5 (2001) (providing basic background on NAFTA's programs to assist dislocated workers).

178. NAFTA-related Job Losses, El Paso Times, June 22, 2003, at 2A.

179. Louie Gilot, Lawsuit over NAFTA Will Head to Court, EL. PAso T1MEs, June 6, 2003, at 1 A.

180. See Training and Education of the Displaced: VF case, UNIDAD Y FUERZA, June 2002, at 2.

181. See Robey, supra note 65 , at 115.

182. See Trefler, supra note 171, at 206; Martin, supra note 172, at 422.

183. Tessie Borden \& Sergio Bustos, NAFTA Lures Immigrants North, EL Paso Times, June 23, 2003 , at $2 \mathrm{~A}$.

184. On January 1, 2003, the protective tariffs on most farm goods were lifted. On December 10, 2002, Mexican farmers rode their horses onto the Chamber of Deputies (Mexico's lower house) in protest. Pav Jordan, Mexican Farmers See Death Sentence in NAFTA (Dec. 28, 2002), at http://www.commondreams.org/headlines02/1228-07.htm. In January, 2003, tens of thousands of 
from states in Mexico with populations not part of a history of migration to the United States now seek work in the United States. ${ }^{185}$ Contributing to the displacement of workers, NAFTA has in some ways encouraged Mexican migration and left the detection and removal of illegal immigrants to border control measures that make the border a site of unnecessary violence. NAFTA also contributes, through its side agreement, to the perpetuation of poor labor conditions on both sides of the border.

Outside the four corners of NAFTA, the NAALC supplemented the agreement and addressed labor concerns largely untouched in NAFTA's text. It, at least symbolically, responded to concerns voiced over the potential that NAFTA created for occupational health and safety violations, gender discrimination in pay and working conditions, and challenges to worker freedom of association. In addition to outlining eleven commonly agreedupon labor principles, it presents procedures for resolving disputes between countries and/or citizens concerning adequate enforcement of the labor principles. ${ }^{186}$ Under the NAALC dispute resolution provisions, only certain of the labor principles - child labor protections, minimum wage technical standards, and the prevention of occupational injuries-may eventually result in fines and trade sanctions. ${ }^{187}$ Just as NAFTA preserves each country's immigration laws, the NAALC preserves each country's labor laws. ${ }^{188}$ Each country undertakes to enforce its own domestic labor laws. Due to poor enforcement, this essentially ensures that Mexican workers will remain vulnerable to low labor standards and low wages. It also nearly guarantees that cheap labor will remain Mexico's comparative advantage.

The NAALC further provides North American countries with standing and a venue through which to challenge each other's enforcement of domestic labor standards. ${ }^{189}$ While this agreement appears to be a mutual commitment to protecting labor rights, it has actually precluded enforcement of labor standards on behalf of immigrant laborers in U.S. courts. For

Mexican farmers marched through the streets of Mexico City "to demand greater protection against U.S. imports under [NAFTA]." E. Eduardo Castillo, Mexican Farmers Stage Mass Protest Against U.S. Imports (Jan. 31, 2003), at http://www.globalexchange.org/campaigns/ftaa/565.html.

185. See Borden \& Bustos, supra note 183 .

186. NAALC, supra note 175 , at annex 1. The eleven labor principles are: (1) freedom of association and protection of the right to organize; (2) the right to bargain collectively; (3) the right to strike; (4) prohibition of forced labor; (5) labor protections for children and young people; (6) minimum employment standards; (7) elimination of employment discrimination; (8) equal pay for men and women; (9) prevention of occupational injurics and illnesses; (10) compensation in cases of occupational injuries and illnesses; and (11) protection of migrant workers. Id.

187. U.S. Gen. Accounting Office, North American free Trade Agreement: U.S. Experience with Environment, Labor, and Investment Dispute SETtlement Cases 23 (2001).

188. NAALC, supra notc 175, at art. 2 ("Affirming full respect for each Party's constitution and recognizing the right of each Party to establish its own labor standards, and to adopt or modify accordingly its labor laws and regulations ....").

189. NAALC, supra note 175 , at Part 5. 
example, the court in Estados Unidos Mexicanos v. DeCoster refused to hear a complaint brought by Mexico on behalf of Mexican workers employed in the United States who alleged civil rights violations and violations of the Migrant and Seasonal Agricultural Workers Protection Act. ${ }^{190}$ The court specifically pointed to the NAALC as the appropriate vehicle for launching such claims. ${ }^{191}$ The NAALC establishes no set criteria for the evaluation of submissions, so the National Administrative Offices (NAOs) in each country exercise a great deal of discretion in deciding which claims to accept. Thus, the unlikelihood of enforcement under the NAALC in effect denies Mexico standing, and the lofty goals articulated under the NAALC provide little to no actual protection due to the extensive dispute resolution procedures. ${ }^{192}$ Lax self-enforcement, ${ }^{193}$ extensive bureaucracy, ${ }^{194}$ and the low probability of penalties ${ }^{195}$ reduce the NAALC to effectively a nonadjudicable wish list for labor protections. The NAALC obliges member countries to enforce their own labor laws, but efforts by one member country to enforce another's labor laws must go through the NAALC's dispute resolution process. The process requires that disputes first go through the alleged violating country's NAO, and the NAO has no criteria to apply to its decision of whether or not to accept a particular dispute. Due to the NAALC's deficiencies and the underenforcement of labor protections, Mexicans in Mexico will remain cheap labor with an incentive to

190. Estados Unidos Mexicanos v. DeCoster, 229 F.3d 332, 343 (1st Cir. 2000).

191. Id. at 341-44.

192. See NAALC, supra note 175, Part 5.

193. See Human Rights Watch, Pub. No. Bi302, Trading Away Rights: The Unfulfilled Promise of NAFTA's Labor Side AgreEment (Apr. 2001), available at http://www.hrw.org/ reports/2001/nafta/ (detailing criticisms of NAALC, including structure, timeliness, and criteria for dispute resolution).

194. The NAALC cstablishes a Labor Commission that consists of a Ministerial Council (the Council) and a Secretariat. The Council, upon which a labor minister from each of the thrce nations sits, functions primarily to oversee NAALC implementation and to facilitate Party-to-Party consultations. The Secretariat consists of five members from each nation. It provides information and reports regarding labor laws, labor market conditions, and human resource development issues. The three NAOs serve as a point of contact for the governmental agencies of the country, the other NAOs, and the Secretariat. Lastly, the NAALC sets up an Evaluation Committee of Experts (ECE) to analyze a Party's enforcement practices. To convene the ECE, the complaint must bc trade-related or covered by mutually recognized labor laws and concern "a pattern of practice by each Party in the enforcement of its occupational safety and health or other technical labor standards . . ." The complaint submission procedure progrcsses from an initial filing with an NAO, to consultation with other NAOs, to Ministerto-Minister consultations, to an ECE review, to the Ministerial Council, to dispute resolution consultations and potentially to fines and sanctions. See NAALC, supra note 175, at arts. 8-9, 14, 16 (creating NAALC's dispute resolution system); U.S. GEN. ACCOUNTING OfFICE, supra note 187 (outlining NAALC's dispute resolution procedures); Teresa R. Favilla-Solano, Comment, Legal Mechanisms for Enforcing Labor Rights Under NAFTA, 18 U. HAw. L. REv. 293, 317-18 (1996) (same).

195. No NAFTA submission has progressed to the dispute resolution phase. U.S. GEN. ACCOUNTING OFFICE, supra note 187 , at 25. 
migrate to the United States, and Mexicans in the United States will be subject to employer abuse without recourse.

The current scheme lays out a U.S.-Mexico trade-migration contradiction: in the long term, prosperity spawned by NAFTA promised to relax the economic push-pull factors and mitigate any incentive for Mexican migration to the United States, ${ }^{196}$ but if the failed enforcement of labor standards ensures the continued benefit of cheap Mexican labor, migration will continue. If Mexican farmers are left without alternative employment in Mexico, migration will continue.

\section{Enhanced Mobility of Professionals}

While immigration and trade remain seemingly separate in regulation, economics, and evaluation, they work together on one point: the legal entry of foreign nationals who enter the United States with money or extensive professional skills. Under both NAFTA and IIRIRA, Mexican nationals with money and extensive professional skills gain easy entry to the United States. Both before and after NAFTA and IIRIRA, U.S. immigration policy has prioritized workers with advanced educational training and capital to invest. In its only substantive modification to existing immigration law, NAFTA modifies one section of the Immigration and Nationality Act to facilitate the movement of professionals. ${ }^{197}$ Inviting persons with wealth and barring lower income entrants provides a specific commentary on the national consciousness: foreigners cannot enter, but foreiguers with enough wealth are welcome to enter, but they cannot stay. Persons formerly considered invaders become contributors defined by capital rather than as labor. Furthermore, because NAFTA authorizes only temporary entry, NAFTA professionals do not challenge the national identity. They retain their foreigner status.

Border peoples gain little from the mobility of Mexican professionals. The twenty-four counties bordering Mexico are among the poorest counties in the United States; only one of those counties sits above the national poverty line. ${ }^{198}$ In assisting the movement of wealthy businesspersons, NAFTA

196. See Gustavo Mohar \& María-Elena Alcaraz, U.S. Border Controls: A Mexican Perspective, in The Wall Around the West, supra note 20, at 139, 141.

197. William J. Benos, The Movement of Professionals, Technicians, and Other Workers Across NAFTA Borders, 8 U.S.-MEx. L.J. 25, 25 (2000) ("With NAFTA, the United States, Canada and Mexico did not intend to create a common market for labor, nor did they seek to harmonize the requirements for business entry between them.").

198. U.S. Census Bureau, Poverty Status in i 1999: Families, Percentage Below Poverty LEVEL, available at http://www.factfinder.census.gov (to find national statistics select "People" from the menu on the left, then select "Poverty Status-Families" from the database list. To search for statistics by country, select "Geography" at the top of the page and narrow the fields to those desired). Only San Diego County, California, with $8.9 \%$ of its families living below the poverty line, is below the national level of $9.2 \%$. For the remaining counties, the percentage of families living below the 
clearly values cross-border mobility but does not specifically consider the mobility or economic prosperity of border peoples. Instead, it accommodates the mobility of investors while the Border Patrol seeks to apprehend and deport most other Mexicans. The policy, which is reflected in immigration and trade laws, indicates that only foreigners with significant capital resources are welcome. Most border peoples would never qualify for entry under such a standard. In twenty-three of the twenty-four U.S. counties bordering Mexico, annual median household incomes fall far below the national median household income of $\$ 41,994 .{ }^{199}$ Seventeen of the counties claim annual median household incomes under $\$ 30,000 .^{200}$

Employment-based immigration law, along with the temporary-entry provisions in NAFTA, prioritizes the cross-border movement of corporate executives, researchers, and professionals with advanced degrees. ${ }^{201}$ People with extraordinary abilities, outstanding professors and researchers, and multinational executives and managers who seek permanent residence in the United States from an employment-based immigrant visa receive first priority and may escape labor certification requirements. ${ }^{202}$ While lower on the priority ladder, investors may also enter without labor certification if they will create a minimum of ten jobs in the United States and invest a minimum of $\$ 1$ million in the United States. ${ }^{203}$ All other categories of persons seeking visas must secure certification by the Department of Labor by showing that there are not sufficient workers in the United States who are able, willing, qualified, and available and that U.S. workers' wages and working conditions will not be adversely affected by the employment of the visa seeker. ${ }^{204}$ Unskilled and agricultural workers seeking to temporarily enter the United States also face labor certification. ${ }^{205}$ Furthermore, persons seeking nonimmigrant visas must prove that they have residence in a foreign country and have no intention of abandoning it. ${ }^{206}$

\footnotetext{
poverty line ranges from $47.4 \%$ (Starr County, Texas) to $10.5 \%$ (Pima County, Arizona). Of the twenty-four counties, the median percentage of families living below the poverty line is $21.5 \%$. Id.

199. Id. Only San Diego County, California, with an annual median household income of $\$ 47,067$ is above the national level.

200. Id. Santa Cruz, California: \$29,710; Dona Ana, New Mexico: $\$ 29,808$; Hidalgo, New Mexico: \$24,819; Luna, New Mexico: \$20,784; Brewster, Texas: $\$ 27,386$; Cameron, Texas: $\$ 26,155$; Culberson, Texas: \$25,822; Hidalgo, Texas: \$24,863; Hudspeth, Texas: 21,045; Kinney, Texas: $\$ 28,320$; Maverick, Texas: $\$ 21,232$; Presidio, Texas: \$19,860; Starr, Texas: $\$ 16,504$; Terrell, Texas: $\$ 24,219$; Val Verde, Texas: $\$ 28,376$; Webb, Texas: $\$ 28,100$; Zapata, Texas: $\$ 26,635$.

201. Thomas MaCurdy, et al., An Economic Framework for Assessing the Fiscal Impacts of Immigration, in The Immigration Debate 13, 51 (James P. Smith \& Barry Edmonston eds., 1998),

202. 8 U.S.C. $\S 1153($ b)(1)(A)-(C) (2000).

203. 8 U.S.C. $\$ 1153($ b) $(5)(2000)$.

204. 8 U.S.C. $\$ 1182(a)(5)(2000)$.

205. 8 U.S.C. $\$ 1188(a)(1)(2000)$.

206. 8 U.S.C. $\$ 1184(2000)$.
} 
"Cross-Border Trade in Services," discussed in Chapter Twelve of NAFTA, focuses on professional services and licensing. ${ }^{207}$ Specifically, Chapter Twelve provides licensing procedures for professional services, foreign legal consultants, engineers, and land transportation services. ${ }^{208}$ The chapter releases any NAFTA party from any obligations to nationals from another country who seek access to the party's employment market. ${ }^{209}$ In addition to the provision of financial, transportation, and professional services, NAFTA liberalizes temporary cross-border movement for certain categories of professionals. ${ }^{210}$ Chapter Twelve does not provide for the integration of NAFTA professionals into the United States, though, since it facilitates temporary entry, not entry with the intent to stay or seek citizenship or permanent residence.

Similarly, NAFTA's Chapter Sixteen designates four categories of visas to facilitate the movement of professionals across the borders: business visitors, traders and investors, intra-company transferees, and professionals. ${ }^{211}$ For all four categories, NAFTA forbids both requisite labor certification tests and numerical quotas for NAFTA visitors. ${ }^{212}$ It also limits fees for temporary entry for businesspersons under this chapter. ${ }^{213}$ Business visitors, the B-1 category of nonimmigrant visa, compose the largest class of business visitors between NAFTA countries. ${ }^{214}$ Persons with significant investments in a NAFTA country qualify for temporary admission as "traders or investors." 215 Other temporary business entries include intracompany transferees and professionals. ${ }^{216}$

207. NAFTA, supra note 7 , at ch. 12 .

208. NAFTA does not require member countries to allow special access to employment for nationals from NAFTA-member countries:

Nothing in this Chapter shall be construed to ... impose any obligation on a Party with respect to a national of another Party seeking access to its employment market, or employed on a permanent basis in its territory, or to confer any right on that national with respect to that access or employmcnt ....

Id. at art. 1201, para. 3.

209. Id. at art. 1201, para. 2(a).

210. Id. at art. 1603, annex 1603 (prioritizing temporary entry for businesspeople on a reciprocal basis).

211. Id. at annex 1603 .

212. See id. at annex 1603 , sections $\mathrm{A}(4), \mathrm{B}(2), \mathrm{C}(2), \mathrm{D}(2)$.

213. Id. at art. 1603(4).

214. Benos, supra note 197 , at 26. "Such persons may enter to (i) engage in commercial transactions that do not involve gainful employment, (ii) negotiate contracts, (iii) consult with business associates, (iv) litigate, (v) participate in scientific, educational, professional or business conventions, conferences or seminars, or (vi) undcrtake indcpendent research." Id.

215. NAFTA, supra note 7 , at annex 1603 , sec. B.

216. William Benos explains: "Specified professionals who meet minimum educational requirements or who possess designated credentials or licensures and experience, and who seek to engage in professional occupations in a NAFTA member country, may be admitted into the United States for up to one year in what is known as the TN category." Benos, supra note 197, at 27. Within the TN category, Canadian nationals bypass some bureaucratic obstacles still facing Mexican nationals. 
NAFTA recognizes the value of investors, managers, and professionals, but it neglects the vast majority of workers affected by the agreement. Current economic elites obtain preferential status and easily bypass the temporary-worker protocol typically imposed on persons seeking to enter the United States. Those seeking unskilled or skilled but not professional employment receive no immigration preference like those afforded to professionals. With this construction, NAFTA unambiguously classifies worthwhile (and undesirable) cross-border mobility.

With NAFTA, wealth buys mobility. The agreement's Chapter Twelve and Sixteen provisions indicate either that wealth may temporarily trump otherness, or, more likely, that wealthy Mexican businesspeople do not threaten the national identity because they will likely remain Mexicans. Border peoples, by contrast, threaten the national identity with their binational ways and failure to fit within the governing understanding of the national interest. If the border shifted 100 miles north, most border peoples would not qualify for the privilege of entry into the United States. In the United States, however, neither the concept of the nation nor that of the national interest would change. Minor modifications to current law could easily accommodate the new geography, and the current border harms would follow the new landscape. The next Part examines possible policy changes and proposes a fundamental reconception of the national interest as the necessary foundation for any worthwhile transformation in border reality.

\section{IV}

\section{A Fundamental RECONCEPTION OF THE NATIONAL INTEREST}

Remedying the harms to border peoples from the bifurcation of trade and immigration policy in the context of U.S.-Mexico relations requires a re-evaluation of the concept of the border and its peoples-a reconception of the national interest. Fundamentally, a remedy or solution demands more than small changes to trade or immigration policy. Better enforcement of current laws similarly offers only a cursory improvement, if any, over the current situation, despite the potential to shift the discourse temporarily to center on border peoples and perhaps raise the consciousness of a few offenders for whom nativistic racism informs their conception of the United States. Enforcing current laws, which build upon a flawed national concept and allowing the current trends in U.S. policy to continue will likely exacerbate the current harms to border peoples. A change in the understanding of the national interest and the subsequent changes in policy are needed and will reflect a comprehensive consideration of the American peoples in a way that allows pluralism, rather than assimilation, to define

Id.; NAFTA, supra note 7 , at annex $1603, \S \mathrm{C}$ (requiring parties to grant temporary entry for business persons and removing labor certification requircments for such persons). 
the nation and the national interest. Pluralism allows us flexibility in our definitions of the term "American" and mandates the active resistance of racial hierarchy. ${ }^{217}$ Racial, ethnic, and cultural groups can maintain group identities without being targeted and distinguished as undesirables, foreigners, or simply others. ${ }^{218}$ Coalition building alone cannot substitute for a model of pluralism, as groups often connect based on particular issues and work together to situate themselves in opposition to policies founded on racial hierarchy. Instead, pluralism could encourage biculturalism and multiculturalism as a norm. ${ }^{219}$

This Part offers examples of three possible policy choices: (1) allowing present trends to continue, (2) seeking more rigorous enforcement of current laws and policies, or (3) enacting innovative policies that build on the existing bifurcation of trade and immigration. It then argues that adequate representation of border peoples and implementation of policies that do not disproportionately burden them requires a fundamental change in the national consciousness. Decision makers, in particular, must reevaluate and revamp their conception of the nation. As long as the national conception remains premised on nativistic racism, policies will continue to create new problems and harm border peoples.

\section{A. The Harms of Continuing Past Trends}

Policy developments, budget allocations, and judicial decisions premised on a foundation of nativistic racism have produced layers of deleterious consequences for border peoples. Without intervention, the harms described in the previous Part will continue on the path toward lost civil rights, increased dangers from smuggling, higher rates of unemployment, and displaced workers. Current trends indicate that ideas about the national interest based on nativistic racism will continue to permeate and dominate policymaking with regard to the U.S.-Mexico border. Free trade will likely soon extend throughout Latin America, ${ }^{220}$ and President Bush has proposed

217. HING, supra note 78, at 176 . Hing writes:

The idea of "being an American" signifies different things to different people. Recognition of these differences helps develop a respect for other cultures and sets the groundwork for a workable multiracial society. This groundwork can help us counter the human tendency to divide and distinguish in binary terms of superiority and inferiority based on racial or cthnic criteria.

Id.

218. See John Higham, Hanging Together: Unity and Diversity in American Culture 112-13 (Carl J. Guarneri ed., 2001) (explaining the basic differences in approach of pluralism and integrationism).

219. HiNG, supra note 78, at 179.

220. See Robert B. Zoellick, Office of the U.S. Trade Representative, The President's TRADE POLICY AGENDA (2004), available at http://ustr.gov/assets/Document_Library/ Reports_Publications/2004/2004_Trade_Policy_Agenda/asset_upload_file931_4751.pdf (naming the Free Trade Area of the Americas as a priority and describing the current status of ncgotiations with countries in the Western Hemisphere); Adam H. Putnam, The Free Trade Area of the Americas: 
increasing militarization along the border to protect the country from threats of terrorism. As a result, the consequences of simultaneously opening and closing the border will continue and intensify.

The threat of terrorism that followed the World Trade Center and Pentagon attacks translated to a lost sense of security and the perceived need to "secure[e] our borders" to guard against future terrorist threats. ${ }^{221}$ The September 11 terrorist attacks substantially intensified the rhetoric of nativistic racism with regard to Southwest border control. Prior to September 11, the escalation of the border policing strategy targeted, at least symbolically, perceived threats to U.S. culture and institutions, in addition to perceived attacks on the U.S. economy and American way of life. ${ }^{222}$ After September 11, terrorism and security concerns dominate the discourse, with illegal immigration remaining a background concern. ${ }^{223}$

On March 1, 2003, DHS was launched with the stated mission of protecting and defending the American people. 1t has three primary missions: (1) preventing terrorist attacks within the United States, (2) reducing America's vulnerability to terrorism, and (3) minimizing the damage from potential attacks and natural disasters. ${ }^{224}$ With five major divisions, DHS purports to "make Americans safer" by combining functions and departments previously housed separately and answerable to different administrative bodies. The largest of the five Directorates is the Border and Transportation Security. It combines the operational aspects of the Transportation Security Administration, the U.S. Customs Service, the Immigration and Naturalization Service and Border Patrol, the Coast Guard, and the Animal and Plant Health Inspection Service of the Department of Agriculture. President Bush's 2003 four-prong national strategy to defend "our homeland" 225 included a $\$ 6.3$ billion increase for the INS alone and aimed to build greater homeland security and combat terrorism. ${ }^{226}$ Over $80 \%$ of the proposed increases in INS personnel were

Opportunities for Economic Growth Through Fair Trade in the Hemisphere, 31 FLA. ST. U. L. REV, 279 (2004).

221. OfFICE OF MGMT. \& Budget, supra note 168 , at 17.

222. See ANDREAS, supra note 22 (arguing that border fortification, at least in part, functions as a symbol).

223. See, e.g., Review of INS Policy on Releasing Illegal Aliens Pending Deportation: Hearing Before the Permanent Subcomm. on Investigations of the Senate Comm. on Governmental Affairs, 107th Cong. (2001) [hereinafter Review of INS Policy].

224. U.S. Department of Homeland Security, DHS Organization: The DHS Transition, at http://www.dhs.gov/dhspublic/display?theme $=10$ \& content $=429$ (last visited July 17, 2004).

225. The strategy, as proposed, includes four missions: (1) ensuring state and local first responders (firemen, police, and rescue workers) are prepared for terrorism; (2) enhancing our defenses against biological attacks; (3) securing our borders; and (4) sharing information and using information technology to secure the homeland. OFFICE OF MGMT. \& BUDGET, supra note 168, at 17.

226. See Immigration \& Naturalization Serv, Office of Pub. Affairs, Executive Summary: The President's Fiscal 2003 Immigration Budget (2002), available at http://uscis.gov/graphics/publicaffairs/ statements/budgetExecSummary.pdf. 
dedicated to border-enforcement operations. ${ }^{227}$ The proposal includes a target level of 11,000 total Border Patrol agents and \$722 million for information technology and information sharing across jurisdictions. ${ }^{228}$ Both pieces of the strategy-information technology and border policing-previously received consideration in some form under NAFTA and IIRIRA, although information technology under NAFTA dealt with the movement of goods. The federal government's fiscal year 2004 budget included a request of $\$ 18.1$ billion for the Border and Transportation Security Directorate alone. ${ }^{229}$

The proposed national security strategy sets the stage for increased civil rights violations at the hands of Border Patrol. The dramatic increases in border policing, combined with the constitutional protection of racial profiling in the border context, will continue to disproportionately impact border peoples. Border peoples have already felt this impact. On February 22, 2003, a Border Patrol agent shot and killed nineteen-year-old Juan Patricio Peraza Quijada, a Mexican immigrant, in central El Paso. ${ }^{230}$ Although Border Patrol agents reported that Quijada threatened them with a piece of metal pipe, no witness could corroborate the agent's story of self-defense. ${ }^{231}$ After the incident, Border Patrol agents intimidated witnesses; according to their attorneys, the agents threatened the witnesses with deportation. ${ }^{232}$ Following the incident, hundreds of community residents gathered to honor the victim and "[w]alk for peace, justice, and rights of immigrant workers." ${ }^{233}$ Border Patrol officials explained that their regulations allow the use of deadly force if an agent is acting to protect his life, the life of another agent, or the life of an innocent person. ${ }^{234}$ More recently, the Border Patrol has been tied to three Mexican immigrant drownings in the Río Grande along the Texas-Mexico border. ${ }^{235}$ According to survivors, Border Patrol agents threw rocks at six persons crossing the river, ordering them to return to Mexico. ${ }^{236}$

The current Southwest Border Strategy has pushed border crossers froin ports of entry in border cities to rural locations. In response, the government has turned its focus to channels of migrant movement outside

227. Id. at 3 (stating that 1,790 of the 2,216 increase in INS positions were for border enforeement).

228. Id. To put these figures in context, a force of 11,000 Border Patrol agents more than doubles the level of agents in fiscal year 1993. See OfFICE of MGMT. \& Budget, supra note 168, at 9.

229. U.S. Department of Homeland Security, DHS Organization: Fiscal Year 2004 Budget Fact Sheet, at http://www.dhs.gov/dhspublic/display?theme=12\&content=431 (last visited July 17, 2004).

230. Michael D. Hernandez, Activists Question Shooting Inquiry, El PASo TIMEs, Feb. 24, 2003, at $4 \mathrm{~B}$.

231. Sáenz, supra note 69.

232. See Hernandez, supra note 230.

233. Sáenz, supra note 69, at 27.

234. Adriana Chávez, Man Slain by Border Agent, El Paso Times, Feb. 23, 2003, at 1 A.

235. John Gonzalez, Drownings Tied to Border Patrol, Houston Chron., Sept. 28, 2004, at B1.

236. Id. 
normal ports of entry. ${ }^{237}$ Ironically, the nontraditional routes now targeted are the very routes created by the INS Southwest Border Strategy and lauded as measures of Border Patrol success. ${ }^{238}$ The use of rural nontraditional routes has led to increased dangers for immigrants because of high temperatures. Immigrant smuggling has gained popular attention as the number of summer deaths has reached dramatic highs. On May 14, 2003, eighteen immigrants were found dead in a trailer at a South Texas truck stop. ${ }^{239}$ When authorities found and opened the abandoned trailer, more than 100 immigrants poured out, desperate for air. ${ }^{240}$ While this instance was among the most highly publicized and dramatic losses of life in the immigrant-smuggling context, it does not stand alone as an anomaly. ${ }^{241}$ In

237. See Review of INS Policy, supra note 223 (introduction by Senator Carl Levin (D-Ml), Chair).

238. See generally GAO, Southwest Border Strategy, supra note 8, at 2 (describing the shift in illegal entries from urban to nonurban border areas). Cf. U.S. Customs \& Border Protection, National Border Patrol Strategy, Feb. 14, 2003, at http:/www.cbp.gov/xp/cgov/enforcement/border_patrol/ strategy.xml (outlining the national Border Patrol strategy of "prevention through deterrence," including the Southwest Border Strategy and Operations Gatekeeper, Hold-the-Line, Rio Grande, and Safeguard).

239. See Tony Freemantle \& Edward Hegstrom, Smugglers' Roads Lead to Houston, HoustoN Chron., May 18, 2003, at 1A; Edward Hegstrom, For Survivors, Ten Minutes Made Difference, Houston Chron., June 6, 2003, at 30A; Edward Hegstrom, Hope Turns to Horror; Eighteen Immigrants Die, Houston Chron., May 15, 2003, available at 2003 WL 3259538.

240. See Frecmantle \& Hegstrom, supra note 239.

241. See Incidents in Which Immigrants Died in Transport, Houston Chron., June 3, 2003, available at http://www.chron.com/cs/CDA/printstory.hts/special/deadlycrossing/1936118. This article documents the following incidents wherc immigrants perished while being transported:

June 3, 2003: Baytown, Texas - The bodies of three illegal immigrants were found aboard a railroad hopper car, two days after fellow immigrants said they had escaped the sweltering car and left behind their weakened companions.

May 14, 2003: Victoria, Texas - 19 dic while being transported by truck. . . They died by dchydration, hyperthermia, and suffocation.

Jan. 9, 2003: Descanso, Calif. - A pickup truck carrying illegal immigrants flipped over during a high-speed chase, killing two people and injuring 13. The truck overturned in southeastern San Diego County, about 20 miles north of the U.S.-Mexican border.

July 27, 2002: Anna, Texas - Two undoeumented immigrants are killed while being transported from El Paso, Texas, to Dallas on a tractor-trailer truck with at least 28 others. Dozens more on the truck were trcated for heat exhaustion. ...

June 24, 2002: San Diego - Six people were killed and 31 injured when a van carrying 27 illegal immigrants smashcd head-on into other vehicles as it went the wrong way on an interstate with its headlights off. .

...

Aug. 29, 2000: Tuscon, Ariz. - A van carrying illegal immigrants crashed on Interstate 10 after a blowout. Three people who were ejected from the vehicle were killed and 17 injured. The van had no seats other than for the driver and front passenger.

...

Feb. 6, 1999: Grants, N.M. - A rental truck carrying 24 illegal immigrants, including the driver, hit an icy patch of road and flipped several times on Interstate 40 , killing one person and injuring the others.

July 23, 1996: Buda, Texas - Two illegal immigrants from Mexico died after being overcome by stifling heat inside the trailer of an 18-wheeler. Dozens of other illegal immigrants survived by climbing out of the truck at a gas station. ... 
2002, according to Border Patrol statistics, 320 undocumented immigrants died in the process of migrating to the United States. ${ }^{242}$

These two examples build on the harms described in the previous Part. Allowing present trends to continue will not only risk the quality of life of border peoples, but it also validates and ensures the continuance of a conception of the national interest that serves only certain populations that fit within a definition of "American" based on nativistic racism.

\section{B. The Inadequacy of Traditional Policy Alternatives}

Two main approaches to policy reform generally surface after identifying a social problem: increase enforcement of current laws or introduce new policies. The current pattern of selective and lax enforcement of some laws certainly poses tremendous problems for border peoples. Heightened enforcement of current laws also poses problems for border peoples because the laws are premised on a notion of the national interest guided by nativistic racism. Innovative new programs of immigration or trade regulation, or both, likewise fail to cure the existing conception of nation and the definition of the national interest. Furthermore, maintaining the isolation of these policies without specifically acknowledging and considering the communities they directly affect will perpetuate the now-prevalent problems.

Because current laws are inadequate, heightened enforcement may compound already existing harms. For example, prosecutors investigating a smuggling operation that ended in the death of nineteen immigrants in South Texas sought to identify and punish those responsible for it. ${ }^{243}$ However, the conditions driving the tragic and lucrative smuggling trade are far more extensive and complicated than the prosecution of defendants in one highly publicized case. The stiffening of penalties for immigrant smugglers was thought to deter the enterprise under IIRIRA; now, these regulations are again expected to act as a deterrent. Instead, the immigrantsmuggling business appears to be growing in profit and sophistication. Given the current structure of immigration enforcement, an increase in enforcement would likely require additional border policing. Increasing the enforcement of immigration and smuggling regulations simply provides little possibility for mitigating the harms to border peoples.

Id.; see also Houston Chronicle, Hot Topic Deadly Crossing, at http://www.chron.com/ content/chronicle/special/03/deadlycrossing/ (last visited Oct. 4, 2004) (listing immigrant deaths while crossing from Mexico into the United States and providing links to corresponding news stories).

242. See Louie Gilot, Three More Immigrants Die, El. PASo Times, June 4, 2003, at A1; see also ESCHBACH ET AL., supra note 42 (studying border-crossing deaths and the specific causes of death over time in the border region).

243. U.S. Attorney: Smugglers Responsible for Deaths, Houston Chron., June 6, 2003, available at http:/www.chron.com/cs/CDA/printstory.hts/special/deadlycrossing/1940800; see also Louie Gilot, People Smuggler Gets Twenty-seven Years, El. PAso Times, June 19, 2003, at B1. 
New and creative legal strategies may succeed in chipping away at the existing body of law or in providing relief for a subset of affected border peoples. For example, the Southern Poverty Law Center and the Mexican American Legal Defense and Educational Fund have filed suit against Ranch Rescue, a vigilante "border watch group" charged with attacking and detaining undocumented immigrants. ${ }^{244}$ While Ranch Rescue is one vigilante-justice group patrolling in rural border areas, others remain in operation. A successful claim against one such organization may chill the practices of others. But, the light or nonexistent fines and sentences imposed on individual ranchers actually inflicting harm and causing death perhaps indicate that vigilante tactics may persist. A case-by-case strategy is never ending, and without a fundamental change in the law, new policies will likely give rise to a new set of harmful results.

Pursuing legal strategies to remedy current problems with Border Patrol also will not work. The legacy of federal caselaw leaves little foundation on which to build a revised or expanded understanding of the national interest. In his Zapata-Ibarra dissent, Judge Wiener laid out his contention with the majority not as against precedent, but as irreconcilable when compared to the protections guaranteed in the Fourth Amendment:

I find inescapable the conclusion that the agent in this case was adjudged to have acted reasonably for Fourth Amendment purposes only because we of the federal judiciary have accepted the proposition that the mission of interdicting illegal aliens (or drugs) in proximity to the Mexican border justifies riding roughshod over the Fourth Amendment guarantees. Signing on to this inverted priority results in our permitting - nay, encouragingagents on roving patrol to conduct warrantless searches, devoid of reasonable suspicion, much less probable cause. How is this practice distinguishable from the former practice of Southern peace officers who randomly stopped black pedestrians to inquire, "Hey, boy, what are you doin' in this neighborhood?". . .

... At least the war that prompted the Supreme Court that to condone the internment of Japanese Americans was a full-fledged, Congressionally-declared, "shooting" war. ${ }^{245}$

244. Lawsuit Targets Border Watch Group, Associated Press, May 30, 2003, available at http://www.chron.com/cs/CDA/ssistory.mpl/special/deadlycrossing/1930864; see also Bob Moser, Vigilante Violence: Crimes Against Border-Crossers are Hard to Detect in the Lonely Arizona Desert but Suspicious Incidents Keep Cropping Up, available at http://www.splcenter.org/intel/intelreport/ article.jsp?sid=9 (last visited June 17, 2004); Southern Propcrty Law Center, Legal Action: Leiva v. Ranch Rescue, at www.splcenter.org/legal/docket/files.jsp?cdrID=44 (explaining the case against Ranch Rescue and its status).

245. United States v. Zapata-lbarra, 223 F.3d 281, 285 (5th Cir. 2000) (Wiener, J., dissenting) (footnote omitted). 
Perhaps challenges to other areas of law would find more favorable precedent. More likely, however, existing precedent coupled with the current anti-terrorism agenda of U.S. immigration policy will preclude significant changes to the national interest as defined by policy. ${ }^{246}$

Another traditional strategy-policy solutions within the framework of current policy-is also unlikely to remedy border harms. One proposal might impose a sliding tax on immigrants based on the extent to which an immigrant might negatively impact the United States; that is, what will it cost the United States economically to support an immigrant? ${ }^{247}$ Based on the debatable assumption that immigrants drain public services, ${ }^{248}$ this proposal converts laborers into commodities and creates an easily identifiable underclass of unskilled foreign workers in the United States. ${ }^{249}$ Assuming that such a proposal would grant workers only temporary status, as did the Bracero program, the class of workers under the proposal would be subject to removal when their presence ceases to be consistent with the national interest. The income tax on legal status would diminish immigrant wages, but immigrant wages would still be higher than those earned elsewhere, so the intended effect of deterring immigrants would likely be undermined. This solution would reinforce unproven theories that immigrants drain public services, ${ }^{250}$ and legitimate nativism as a vision for immigration policy. ${ }^{251}$

A second far-reaching, labor-based immigration proposal might challenge the current conception of immigration, also by building on the popular assumption that illegal immigrants are a drain on the system. ${ }^{252}$ This proposal would document all immigrants and grant provisional legal status, pending their ability to find employment. ${ }^{253}$ Within a prescribed amount of time, immigrants would confirm employment and could apply for legal

246. See Richard A. Boswell, Racism and U.S. Immigration Law: Prospects for Reform After “9/11?," 7 J. GENDER RACE \& JUST. 315, 332-46 (2003) (analyzing the structural, attitudinal, and doctrinal barriers to immigration reform).

247. See Chang, supra note 29 , at 372.

248. See generally George J. Borjas, Heaven's Door (1999); George J. Borjas, The Labor Demand Curve Is Downward Sloping: Reexamining the Impact of Immigration on the Labor Market, (Nat'l Bureau of Econ. Research, Working Paper No. 9755, 2003) (estimating the labor-market impact of immigration by comparing immigrants with citizens of equal education and concluding that immigration lowers the wages of competing workers). For a comprehensive synopsis of the varying arguments surrounding the costs of immigrants to the United States, scc HrNG, supra note 78, at 76104. For a critical review of empirical studies on the effects of immigration on native workers, see Chang, supra note 29 , at $305-08$.

249. Cf. Calavita, supra note 47 (documenting the Bracero program, including its creation of a captive labor force and endemic abuse).

250. See SIMON, supra notc 11, at 314 (rebutting the popular understanding that immigrants drain public services systems).

251. For another take on taxing immigrants, see Chang, supra note 29 , at $378-408$ (suggcsting that skilled immigrants should be allowed entry without restriction, and unskillcd immigrants should be allowed entry subject to less generous fiscal policies than those afforded to natives).

252. See Schulz, supra note 136, at 158-62 (introducing a policy of labor-bascd immigration).

253. Id. at $159-60$. 
residency status. Without proof of employment, immigrants would be deemed deportable. The difficulty with this proposal lies in its implementation. For those immigrants who fail to find employment, reporting back to relinquish legal status is unlikely. While these policy ideas may defy sometimes-popular conceptions of the contributions of immigrants, neither will remedy the harms brought by a national conception grounded in nativistic racism.

Minor modifications to the current trade system are similarly inadequate, although NAFTA may be a better starting point due to its focus on the border. An expanded free trade zone that fails to consider labor migration, however, will likely continue on the current trends exacerbating harms to border peoples. ${ }^{254}$ Adjustments to free trade require special attention to the border and bordering nations. Renegotiations cannot change the conditions created by the current separation without a significant change in the national concept to value border peoples.

More likely than including immigration talks in free trade negotiations is the incorporation of immigration into the trade agenda in the form of a temporary-worker program. On January 7, 2004, President Bush proposed a new temporary-worker program. ${ }^{255}$ The proposal purports to "match willing foreign workers with willing U.S. employers when no Americans can be found to fill the jobs."256 Attempting to open the supply of migrant workers to fill employers' demand, the proposal requires that employers make every effort to find Americans to fill jobs before resorting to foreign laborers. However, it does not define the criteria for finding an American worker or specify the amount of time required to elapse before a foreign worker may be legally employed. The proposal also purports to "promote compassion" by granting current undocumented workers a temporaryworker card that would enable them to freely travel back and forth between their home country and the United States. ${ }^{257}$ The legal status granted by the temporary-worker card would last three years. ${ }^{258}$ With this timetable, Bush's proposal holds the potential for the human and civil rights violations that accompanied the Bracero program for migrant farmworkers.

254. A trade agreement that expands NAFTA throughout the Western Hemisphere is currently in the works. Office of the U.S. Trade Representative, Trade Facts: Free Trade Area of the AMERICAS (2003), available at http://www.ustr.gov/assets/Document_Library/Fact_Sheets/2003/ asset_upload_file962_3466.pdf. The Bush Administration touts the Free Trade Area of the Americas (FTAA) as "a plan that would foster economic growth and opportunity, promote regional integration and strengthen democracies." $/ d$. Additional information on FTAA is available on the official website of the FTAA at http://www.ftaa-alca.org/alca_e.asp (last visited July 18, 2004).

255. Press Release, White House, Fact Sheet: Fair and Secure Immigration Reform (Jan. 7, 2004), available at http://www.whitehouse.gov/news/releases/2004/01/20040107-1.html.

256. Id.

257. Id.

258. Id. President Bush enters this caveat by encouraging immigrants to return to their countries of origin through incentives. Id. The proposal provides that the card may be renewable (but does not define terms for renewal), and states that the temporary status would have an end. $I d$. 
When (1) temporary workers are no longer deemed necessary to U.S. employers, (2) temporary workers have exhausted their legal stay, or (3) nativistic racism again rears its ugly head, removal policies in the style of Operation Wetback and workplace raids will soon follow. ${ }^{259}$ The ensuing civil rights violations affect all border peoples, as the Fourth Amendment provides little protection.

Common approaches to policy reform miss the mark with regard to the U.S.-Mexico border. Policy proposals for both immigration and trade, which are continually designed using economic rationales, require the policies to operate in virtual isolation of each other. As new policy proposals are developed and evaluated, national economic standards will likely prevail as criteria by which to judge the efficacy of their plans. Without a deeper evaluation of the policies and their latent motivations, policies such as IIRIRA and NAFTA will continue to devastate border peoples.

\section{Redefining the National Interest}

The practical collision of trade and immigration generates unrelenting consequences for border peoples. Predictably, the trade-migration interaction poses difficult policy questions. Ordinary approaches to changing national policy will not adequately address border harms because they will continue to be masked by economic justifications that purport to serve the national interest. The nativistic racism that underlies the reigning conception of the national interest must be confronted and changed to allow for a pluralistic approach to policymaking.

One starting point for reimagining the national interest may be judicial intervention to reform Fourth Amendment jurisprudence as it relates to the border. A small step, indeed, but it may begin to reverse the decades of Fourth Amendment deterioration that has condoned and encouraged reductions in human and civil rights for border peoples. As a starting point, this would strike against nativistic racism and current national-interest notions by rejecting the finding that Mexican appearance may indicate illegal presence. It would also be a step toward recognizing the fluidity of the border. For border peoples, Mexican appearance is just as likely to indicate citizenship as it is to indicate unauthorized status. Through reforming Fourth Amendment jurisprudence, we could begin to reconceive the nation by recognizing the superficiality of the border and by tolerating the ambiguities in identity currently rejected by a nativistic racism-informed nation.

A second starting point may be legislation to decriminalize immigration and remove border controls as we currently know them. ${ }^{260}$ Under current U.S. policy, immigrants are criminals, and border militarization is,

259. See CAlAvita, supra note 47, at 49-61 (describing Operation Wetback).

260. See generally Johnson, supra note 78, at 245-63 (proposing extensive changes to immigration law as it currently exists). 
to some extent, justified by the drive to punish and remove criminals. Decriminalizing immigration and demilitarizing the border would likely solve some of the harms described above. For example, immigrant smuggling would disappear; there would be no market for a people-smuggling industry. Abuse by Border Patrol would fall dramatically, as their function would shift to detecting and apprehending dangerous and otherwisecriminal entrants. Decriminalizing the entry of foreign nationals assists the project of reconceiving the national interest by challenging the prevalent definition of the term "immigrant" as illegal and alien. It allows for a literal blurring of the border. Removing immigration controls, both on paper and along the border, would challenge racial hierarchy by rejecting any commitment to insulating and narrowly defining American culture and norms of belonging.

At its core, a pluralistic approach requires that racial hierarchy be dismantled and the definition of American and the corresponding national interest be transformed. Group identities can flourish without being labeled foreign or undesirable. Furthermore, foreign need not equate to undesirable. The approach envisions a "viable multiethnic, multiracial society that recognizes a need for separatism in certain sectors, yet simultaneously urges some form of common American political identity."261 American need not be narrowly defined, and border peoples need not be made subject to artificial definition through-as is often true along the U.S.-Mexico border-a line in the sand.

What would it mean to confront nativistic racism and reconceive of the national interest? The border must be understood not as a hard-and-fast demarcation line, but the site of a complex and often ambiguous relationship. We must come to understand the border as a political one that does not require policing to exist or function. The site of economic, social, and cultural symbiosis, the U.S.-Mexico border and its peoples should be understood as such. The fortification of the border with policing agents and concrete-and-barbed-wire walls has not and will not alter the symbiotic relationship; rather, it physically scars the nation. An appreciation of the multifaceted nature of the border and its people should be at the beginning of a reconception of the nation.

In undertaking the reconception of the nation, pluralism must be taken seriously as the democratic goal rather than as the reluctant or temporary alternative to assimilation. Decision makers should favor a policy of preserving distinctive groups within the nation instead of proceeding with a definition of nation that excludes and harms certain peoples. Perhaps decision makers are waiting for border peoples to gain benefit from policies once they assimilate under the reigning umbrella of the national interest. Even if that interpretation holds true, the policies are drafted with border 
peoples carved out of consideration. Pluralism offers an alternative to the current conception of the nation, as it allows for group-based cultural, ethnic, and racial differences without requiring certain peoples to opt out of consideration in U.S. policymaking. The national interest must come to include border peoples such that far-removed majoritarian principles of democracy give way to pluralism.

\section{CONCLUSION}

On March 12, 2003, members of Congress announced the formation of the U.S.-Mexico Congressional Caucus. ${ }^{262}$ It aims to improve the economic bonds between the two countries and will concentrate on strengthening the U.S.-Mexico trade relationship. ${ }^{263}$ At a press conference in Washington, D.C., the economic relationship between the two countries was cited as of paramount importance. ${ }^{264}$ Immigration was said to be an "ancillary" issue. ${ }^{265}$ The national interest, which is framed as the economic interest, persists as the framework for discussing and enacting policies chiefly and tangibly affecting border peoples.

There is no simple solution. Policies fundamentally based on a nativistic racist conception of the border will continue to generate new problems. Small changes to current immigration and trade policies are insufficient to adequately redefine the concept of the national interest. A policy to reconcile immigration and trade between the United States and Mexico should recognize the social and economic interdependence of the bordering nations, as well as the effects of border fortification on border peoples. Any remaining symbolic value of border control should collapse under the weight of damage inflicted as a result of conflicting though coexisting policies. ${ }^{266}$ Of paramount importance must be a reconception of the nation and the dismantling of social understandings that preclude the full consideration of the border and its peoples in policymaking. A reconception of the border requires that we take pluralism seriously and redefine the national interest accordingly.

262. News Release, Congressman David Dreier, Dreier, Stenholm Launch U.S.-Mexico Congressional Caucus (Mar. 12, 2003) (on file with the California Law Review).

263. Id.

264. See Sergio Bustos, U.S. Border Panel to Deal with Trade, Not Immigration, El Paso Times, Mar. 13, 2003, at 4B.

265. Id.

266. See generally ANDREAs, supra note 22, at 7-9 (analyzing the symbolic nature of border control). 